\title{
Long-Term Outlook for Global Natural Uranium and Uranium Enrichment Supply and Demand Situations after the Impact of Fukushima Daiichi Nuclear Power Plant Accident
}

\author{
Yuhji MATSUO ${ }^{1, *}$ and Tomoko MURAKAMI ${ }^{2}$ \\ 1,2 The Institute of Energy Economics, 1-13-1 Kachidoki, Chuo-ku, Tokyo 104-0054, Japan
}

\begin{abstract}
In this paper, the authors propose long-term projections of global nuclear power generation, uranium production, and uranium enrichment capacities by region, and estimate the trade flows of natural uranium and uranium enrichment activities in 2020 and 2035. In spite of the rapid nuclear power generation capacity growth expected especially in Asia, natural uranium and uranium enrichment trade will not be tightened by 2020 . This is due to the projected increase in both natural uranium production and uranium enrichment capacities, which may cause a drop in natural uranium and uranium enrichment prices. Therefore, there is a strong possibility that current capacity expansion projects will be considerably delayed. However, in the "high demand scenario", where nuclear expansion will be accelerated due to growing concerns about global warming and energy security issues, additional investments in uranium production and enrichment facilities will be required by 2035. In Asia, the self-sufficiency ratio for both natural uranium supply and uranium enrichment activities will remain relatively low until 2035. However, the Herfindahl-Hirschman $(\mathrm{HH})$ index of natural uranium and uranium enrichment activity trade to Asia will be lowered considerably up to 2035 , indicating that nuclear capacity expansion can contribute to enhancing energy security in Asia.
\end{abstract}

KEYWORDS: nuclear fuels, enrichment, natural uranium resources, uranium production, reprocessing, tail assay, outlook, trade balance, numerical analysis, self-sufficiency, energy security

\section{Introduction}

The Fukushima Daiichi Nuclear Power Plant Accident in the wake of the Great East Japan Earthquake caused the massive release of radioactive materials and the long-term evacuation of local residents. This accident had a large impact on nuclear energy policies both in Japan and overseas countries. According to the Strategic Energy Plan ${ }^{1)}$, the Japanese government had originally aimed to newly build nine nuclear power reactors and fourteen reactors by 2020 and 2030 , respectively. However, these plans are now under review because of the accident, and a significant revision of the nuclear energy policy is definitely required. Nevertheless, Japan is

* Corresponding author, E-mail: matsuo@edmc.ieej.or.jp

DOI : 10.15669/fukushimainsights. Vol.4.138

(C) 2021 Atomic Energy Society of Japan. All rights reserved.

Originally published in Transactions of the Atomic Energy Society of Japan (ISSN 1347-2879), Vol. 11, No. 4, p.281-303

(2012) in Japanese. (Japanese version accepted: August 31, 2012) 
required by international legislation to reduce greenhouse gas emissions, and it is unclear how the country now views the role of nuclear energy in this respect.

Immediately after the Fukushima Accident, Germany stopped the operation of seven old nuclear reactors and adopted a policy to successively decommission the remaining reactors by 2021. Furthermore, Italy had stopped operation of all nuclear power plants but had recently considered building new nuclear power plants; however, following a national referendum after the accident, over $90 \%$ of the nation were found to be opposed to resuming the program for building new nuclear power plants. Thus, the Fukushima Accident had a direct impact on certain European countries. In Asian countries (especially China and India), where a rapid future growth in power demand is expected, there has been no change in the situation, and a rapid expansion of the generating capacity of nuclear power plants is still expected. Similarly, in countries with advanced nuclear technologies (including the US, France, Russia, and Korea), no changes have been made to their nuclear policies, as these enable industrial development, the provision of a stable energy supply, and the potential to reduce greenhouse gas emissions.

Therefore, at least in the current situation, the expansion of nuclear energy use is expected to continue worldwide in the long term, because it provides the means to reduce fossil fuel consumption and greenhouse gas emissions.

When considering long-term perspectives of nuclear power generation, one of the most important issues is uranium resource availability. The demand for uranium will continue to expand in the long term, as long as we continue using the current light-water reactor (LWR) technologies. However, several factors could contribute to mitigating the demand expansion, such as policy changes after the Fukushima Accident, the introduction of Fast Breeder Reactors (FBRs), and a fuel transition by introducing the thorium cycle. Nevertheless, even when considering these factors, an increased demand is still expected. It is thus significantly important to evaluate whether a sufficient amount of uranium can be supplied, and if so, where and how much can be supplied, as this will enable the country to plan for the development of future nuclear power generation with respect to the growing demand for global energy and requirements to reduce greenhouse gas emission. In addition, for the use of existing LWRs, which use enriched uranium as fuel, it is necessary to consider the uranium enrichment (UE) supply capacity when considering the supply and demand of uranium, because demand for natural uranium (NU) and an amount of UE services have a trade-off relationship.

As nuclear power generation provides a significant proportion of energy supplies, various organizations (including the International Energy Agency (IEA) ${ }^{2,3)}$, the International Atomic Energy Agency (IAEA) ${ }^{4}$, the Organisation for Economic Co-operation and Development $(\mathrm{OECD})^{5)}$, United States Department of Energy (U.S. DOE) ${ }^{6}$ and the World Nuclear Association (WNA) ${ }^{7}$ have provided future nuclear outlooks. When future energy demands or power generation are forecast, it is common to use econometrics or cost-optimization models. However, as nuclear power development is largely dependent on national policies, nuclear power generation projections are made based on detailed research of current energy supplies, demand situations, and energy policies, rather than on these models. Such a method appears to be particular to the nuclear energy outlook.

The future uranium production outlooks include those provided by the $\mathrm{OECD}^{8)}$ and $\mathrm{WNA}^{9)}$; these examine uranium mines and their development projects and estimate the uranium production of each country, region, and the world, and associated future expansion based on the study results. However, these outlooks are more valuable as a reference material rather than providing a calculation method.

Few studies have used the supply and demand prospects to conduct a detailed analysis of future uranium demands. For example, Komiyama et al. ${ }^{10)}$ evaluated uranium supply and 
demand scenarios by 2030 and 2100 and derived policy implications by uniquely projecting the future global nuclear power generating capacity; their study referred to the OECD's uranium supply and demand forecast. However, the study separately simulated the global demand and production of uranium and evaluated surplus production and supply shortages by comparing simulation results, and it did not sufficiently consider elements specific to nuclear fuel, such as UE. Murakami ${ }^{11)}$ took this a step further and found that the possibility of tight supply-demand situations of NU in 2030 will largely change due to the changes in tail assay, considering demand of NU and UE service demand become trade-off relationship by changing tail assay in uranium enrichment. However, in this respect, only the relationship between the NU demand, the amount of UE services, and enriched uranium demand were globally recognized, and the study does not answer detailed questions such as what the supply and demand of uranium will be in Asia, which will be the core region where nuclear power generation will expand in the future. As most of the trade transactions and cost data are not disclosed, there are a lack of studies that forecast future trade flow by region.

Therefore, by referring to the world energy supply and demand outlook ${ }^{12)}$ created by the authors, this study provides a projection of nuclear power generation by global region, and evaluates the future demand for NU and the generating capacity of UE plants by referring to previous studies and using information obtained from websites of nuclear related companies. By considering the results and referring to current records as of 2009 , we then estimate the future trade flow based on the proposed evaluation model using the least-squares method.

The contribution of this study is twofold: first, the study includes observations about a possibility of long-run supply of uranium by estimating the world supply and demand amounts of NU and UE services until 2035 in consideration of their relationship with prices. Generally a shear of fuel cost on power generation cost of nuclear power is low, and then, nuclear power plant construction plans are affected by national policies as first, and construction cost and money supply circumstances as second. Once a nuclear power plant is established, it generates power as much as possible as a basic electricity supplier, from the view points of economy. Therefore, fuel prices have a low impact on the amount of electricity generated by nuclear power and the demand for uranium fuel. On the other hand, the relative relationship between prices of NU and UE affects cost optimum tails, and changes the demands of NU and UE through tails. This study evaluates their supply and demand balance in 2020 and 2035 based on this relationship.

Second, this study provides a regional fuel supply and demand balance by estimating future trade flow, especially the supply and demand trends in Asia, where a rapid growth in future energy demand is expected. It is anticipated that the domestic production of fossil fuels in Asia will not be able to meet the demand expansion, and Asian countries will need to depend more on other regions, such as the Middle East ${ }^{12}$. Therefore, increasing the amount of nuclear power generation would mean diversification of energy supply; however, it is unclear how much dependence on foreign energy sources, through production and UE service, can be reduced.

From these perspectives, providing an estimate of future trade flows has not yet been attempted in previous studies.

\section{Methodology and Assumptions}

\section{Outlook for Nuclear Generating Capacity and Demand for Uranium}

\section{(1) Nuclear generating capacity}

Immediately after the Fukushima Accident, Germany halted operation of its seven domestic 
nuclear reactors that had been in operation prior to 1980 . This halt was said to have been expedited in lieu of the facilities being confirmed safe; however, on June 6, 2011, the government adopted a policy to immediately decommission the seven reactors, and to decommission the remaining nuclear reactors from 2013 to 2021. A national referendum was held in Italy to obtain consensus as to whether operation of the nuclear reactors should be resumed, and over $90 \%$ of the nation opposed the motion; therefore, Italy will not resume its nuclear program for the foreseeable future. However, while the Fukushima Accident had a direct impact on some countries, especially those in Europe, and forced them to stop depending on nuclear power, certain countries retained their nuclear promotion policies: countries such as the US, France, Russia, and Korea, which have actively promoted nuclear energy generation for many years, and emerging countries such as China and India.

In light of such circumstances, this study uses current policies, power development plans, and energy supply and demand trends to provide a forecast until the year 2035 of the nuclear generating capacities of all countries that currently use and will possibly use nuclear power. Based on this forecast, we then estimate nuclear generating capacities by region for North America, Latin America, Europe, Africa, the former Soviet Union (FSU), the Middle East, and Asia. The estimation is based on two scenarios: a high demand scenario and a low demand scenario. In the former scenario, it is assumed that countries will actively continue expanding their nuclear generating capacities; and in the latter, it is assumed the Fukushima Accident had a maximum impact on nuclear policies or that other issues, such as funding, are hampering nuclear development. Overviews of these scenarios per region are as follows:

(a) North America

The US is the largest nuclear power player with 103 nuclear power reactors in operation. However, as previously mentioned, recent nuclear power plant construction initiatives have not been very successful despite it previously being referred to as the Nuclear Renaissance. This is because of the rapid growth in unconventional natural gas production and also that the use of nuclear energy is not the largest mean of reducing greenhouse gas emissions for the US ${ }^{13)}$. However, a combined construction and operation license (COL) was issued in 2012 for the first time, their policy to retain and expand their nuclear generating capacity is still firmly maintained: a 60-year operational life extension has been approved for over half of existing nuclear reactors and another 20-year operational life extension is also being considered. In the low demand scenario, it is assumed that the generation capacity will increase by approximately only $10 \mathrm{GW}$ by 2035 , which is in line with the projection by the U.S. Department of Energy ${ }^{14)}$; and in the high demand scenario, it is assumed power plant capacity will increase up to $130 \mathrm{GW}$ by 2035 , with respect to construction of nuclear reactors that are currently in the planning stage.

Canada is a country with a long nuclear power development history that mainly uses the country's unique heavy water reactor (HWR) technology. Ontario province, which has the largest energy demand and is home to 16 of the 18 nuclear reactors in the country, plans to expand its nuclear generating capacity ${ }^{15)}$.

Therefore, it is assumed that the nuclear generating capacity of North America will gradually increase from $119 \mathrm{GW}$ in 2010 up to $129 \mathrm{GW}$ in 2035 in the low demand scenario, and up to $147 \mathrm{GW}$ in the high demand scenario.

(b) Latin America

The Latin American countries currently using nuclear energy are Mexico, Brazil, and Argentina. In Mexico, it is assumed that the capacity of nuclear power plants will increase slightly due to power uprates. In Brazil, two power plants are currently in operation at $2.0 \mathrm{GW}$. The construction of Angra III has been suspended, but this is expected to be resumed, and operation is scheduled to start in 2013. Brazil's nuclear power generation capacity may increase 
significantly with a future growth in energy demands. In Argentina, two nuclear reactors are in operation at $1 \mathrm{GW}$, one of which is likely to be decommissioned before 2030. In this country, construction of a heavy-water reactor (Atucha II) was underway as the third nuclear reactor, but this was suspended in 1994 due to financial difficulties and other reasons. Although construction of this plant is expected to be resumed in the future, in the low demand scenario it was considered that the construction would not be resumed, mainly because of financial issues. However, a few new constructions were assumed in the high demand scenario.

Thus, it is assumed that the nuclear generating capacity of Latin America will increase from $4 \mathrm{GW}$ in 2010 to $6 \mathrm{GW}$ in 2035 in the low demand scenario, and to $17 \mathrm{GW}$ in the high demand scenario.

(c) Europe

In Europe, many nuclear reactors were constructed between 1970s and 1980s and the generation capacity has rapidly expanded. However, owing to the lack of relative competitiveness of nuclear power associated with low crude oil prices, there was a reduction in the construction of new nuclear power plants. Moreover, in some countries, policies included decommissioning of nuclear reactors stepwise have been taken.

In France, where utilization of nuclear power is widespread most, François Hollande expressed a commitment to reducing the share of nuclear power in national electricity generation down to $50 \%$ by 2025 , when he won the presidential election in 2012 . However, it is highly likely that the country will not to make any changes for a while, given that a schedule for closing nuclear reactors has not yet been provided, and it was announced in April 2012 that the nuclear agreement previously signed with the Green Party would be terminated.

In this study, we assume that France will retain its current high nuclear share until 2035. However, we assume that countries including Germany, Italy, Switzerland, and Belgium, that identified their clear direction toward a nuclear phase-out after the Fukushima Accident, will completely eliminate their nuclear power plants by 2030 in the low demand scenario. Meanwhile, as in the example of Sweden, that has not yet achieved nuclear power phase-out policies that were previously determined, we assumed that these countries will also retain parts of their nuclear generating capacities in 2035 in the high demand scenario.

In the future, although new nuclear power plants will be constructed at a certain level in Europe, it is supposed that the overall nuclear generating capacity will remain at the same level, or it will slightly decline because many existing aging reactors will be decommissioned. In consideration of the above situations, it is assumed that the nuclear generating capacity of $141 \mathrm{GW}$ in 2010 will decline to $107 \mathrm{GW}$ in 2035 in the low demand scenario and increase to $161 \mathrm{GW}$ in the high demand scenario.

(d) Former Soviet Union

The countries in the former Soviet Union with large nuclear generating capacities are Russia and the Ukraine. Russia is one of the world's largest oil and gas producers, and it regards its energy resources as key tools in achieving diplomatic relations. No major changes have been seen in Russia's nuclear policies, as previously mentioned. In addition, the Ukraine is supposed to continue building new nuclear reactors and has been planning to construct 14 new units by 2030 .

This region (and Russia in particular) is expected to largely enhance its nuclear generating capacity by 2035 . In this study, the capacity is assumed to increase from $37 \mathrm{GW}$ in 2010 to $59 \mathrm{GW}$ in 2035 in the low demand scenario, and to $85 \mathrm{GW}$ in the high demand scenario in 2035. In the high demand scenario, new nuclear power plant construction in Kazakhstan is also assumed.

(e) Middle East, Africa, and Oceania 
The Middle East is a large oil and gas producing area; however, many countries in the area have recently begun to consider implementing nuclear energy with the aim of diversifying energy resources and desalinating seawater. To be more specific, not only Iran, which has imported an LWR from Russia and has been uniquely developing nuclear energy, but also the UAE, Saudi Arabia, Kuwait, and Jordan are considering constructing new nuclear power plants. The UAE has already decided to construct a new nuclear plant and placed an order to a Korean plant manufacturer. In this study, we assumed that only the UAE would construct new nuclear reactors by 2035 in the low demand scenario, and in the high demand scenario other countries also proceed with power plant construction.

In the African continent, French LWRs have been in operation since 1984 in South Africa. The country planned to introduce their uniquely developed gas reactor, called the Pebble Bed Modular Reactor (PBMR), in the future, but this has been delayed due to the country's economic deterioration. We assume that South Africa's nuclear generating capacity will not increase from $1.9 \mathrm{GW}$ in 2010 in the low demand scenario, but that it will increase up to $6 \mathrm{GW}$ in 2035 in the high demand scenario.

(f) Asia

Even in the 1990s, when new nuclear power plant construction was stagnant in Europe and the US, Asian countries (including Japan and Korea) continued to construct new nuclear power plants. Today, emerging Asian countries (such as China, India, and those in Southeast Asia) have begun to show a rapid increasing interest in nuclear power generation, and it is expected that most new global nuclear power plant construction will be conducted in Asia.

Prior to the Fukushima Accident, China had 13 nuclear reactors in operation in early 2011, with an output of $10.85 \mathrm{GW}$ and another 30 power plants with an output of $33 \mathrm{GW}$ (which is about three times more than its current capacity) under construction at that time. However, after the accident, China suspended approvals for new construction plans, which forced them to slightly delay their new plans to construct plants providing a capacity of 70 to $80 \mathrm{GW}$ by 2020. Nevertheless, they moved steadily forward with the construction of the new plants that had been approved before the accident, and are expected to resume construction of new power plants once their safety has been confirmed. Rapid progress is expected in China towards such new power plant construction. India is also planning the large scale construction of LWRs with foreign technology, along with development employing the thorium cycle using their domestic resources, which they have been engaged with for a long period of time. No change was made to India's nuclear policy following the Fukushima Accident, as seen by the launch of the new Rajasthan VII and VIII constructions in July 2011.

In the high demand scenario, it is assumed that a great number of power plants will be constructed in line with national targets, whereas in the low demand scenario, we assumed lower nuclear capacities due to minor changes in nuclear policies made after the Fukushima Accident. In Southeast Asian countries, nuclear policies are being reviewed in the wake of the accident. In the low demand scenario, no new construction is expected until 2035, except in Vietnam where a concrete construction plan is already underway. The high demand scenario assumes that about four nuclear power plants per country will be constructed.

Therefore, in Asia, it is assumed that the nuclear power generation capacity will increase from $85 \mathrm{GW}$ in 2010 to $190 \mathrm{GW}$ in 2035 in the low demand scenario, but this will rapidly increase to $347 \mathrm{GW}$ in the high demand scenario.

These results indicate that the global generating capacity of nuclear power plants will increase from $390 \mathrm{GW}$ in 2010 to $795 \mathrm{GW}$ in 2035 in the high demand scenario and to $500 \mathrm{GW}$ in 2035 in the low demand scenario. The assumptions by country are shown in Table 1.

However, even in the high demand scenario, if we assume a future power demand growth, 
Table 1 Nuclear generating capacity outlook

Unit: GW

\begin{tabular}{|c|c|c|c|c|c|}
\hline & \multirow[t]{2}{*}{2010} & \multicolumn{2}{|c|}{$\begin{array}{l}\text { Low demand } \\
\text { scenario }\end{array}$} & \multicolumn{2}{|c|}{$\begin{array}{l}\text { High demand } \\
\text { scenario }\end{array}$} \\
\hline & & 2020 & 2035 & 2020 & 2035 \\
\hline North America & 118.6 & 129.0 & 129.0 & 129.1 & 146.7 \\
\hline USA & 105.3 & 115.8 & 115.8 & 114.7 & 130.4 \\
\hline Canada & 13.3 & 13.2 & 13.2 & 14.4 & 16.3 \\
\hline Latin America & 4.4 & 6.0 & 5.6 & 9.2 & 16.6 \\
\hline Mexico & 1.4 & 1.6 & 1.6 & 1.6 & 1.6 \\
\hline Brazil & 2.0 & 3.4 & 3.4 & 5.8 & 12.2 \\
\hline Argentina & 1.0 & 1.0 & 0.6 & 1.8 & 2.7 \\
\hline Europe & 141.3 & 126.5 & 107.3 & 146.0 & 161.3 \\
\hline UK & 12.0 & 7.8 & 6.5 & 10.4 & 11.7 \\
\hline Germany & 21.5 & 8.6 & 0.0 & 12.7 & 12.7 \\
\hline France & 66.0 & 67.5 & 67.5 & 67.5 & 69.1 \\
\hline Italy & 0.0 & 0.0 & 0.0 & 3.2 & 6.4 \\
\hline Turkey & 0.0 & 0.0 & 0.0 & 2.6 & 5.2 \\
\hline Sweden & 9.4 & 10.0 & 8.9 & 10.0 & 11.3 \\
\hline Spain & 7.7 & 7.3 & 7.3 & 7.3 & 8.6 \\
\hline Belgium & 6.2 & 4.3 & 0.0 & 5.5 & 5.5 \\
\hline Switzerland & 3.4 & 1.2 & 0.0 & 3.4 & 1.9 \\
\hline Finland & 2.8 & 5.8 & 5.8 & 7.4 & 7.4 \\
\hline Netherlands & 0.5 & 0.0 & 0.0 & 0.5 & 3.1 \\
\hline Slovakia & 1.9 & 1.9 & 1.9 & 2.6 & 2.6 \\
\hline Hungary & 1.9 & 2.0 & 0.0 & 2.0 & 2.0 \\
\hline Czech & 3.9 & 4.0 & 4.0 & 4.0 & 5.1 \\
\hline Burgaria & 2.0 & 4.2 & 4.2 & 4.2 & 4.2 \\
\hline Slovenia & 0.7 & 0.7 & 0.0 & 0.7 & 1.8 \\
\hline Romania & 1.4 & 1.4 & 1.4 & 2.1 & 2.8 \\
\hline Africa & 1.9 & 1.9 & 1.9 & 1.9 & 5.8 \\
\hline S. Africa & 1.9 & 1.9 & 1.9 & 1.9 & 5.8 \\
\hline $\mathrm{FSU}^{\mathrm{a})}$ & 37.4 & 43.7 & 59.3 & 61.5 & 85.5 \\
\hline Russia & 23.2 & 26.2 & 39.5 & 42.5 & 57.7 \\
\hline Ukraine & 13.8 & 16.0 & 18.2 & 16.0 & 20.4 \\
\hline Armenia & 0.4 & 0.0 & 0.0 & 0.4 & 0.4 \\
\hline Kazakhstan & 0.0 & 0.0 & 0.0 & 1.1 & 4.4 \\
\hline Lithuania & 0.0 & 1.5 & 1.5 & 1.5 & 1.5 \\
\hline Belarus & 0.0 & 0.0 & 0.0 & 0.0 & 1.1 \\
\hline Middle East & 1.0 & 1.0 & 6.6 & 6.2 & 31.8 \\
\hline Iran & 1.0 & 1.0 & 1.0 & 2.3 & 4.9 \\
\hline UAE & 0.0 & 0.0 & 5.6 & 2.8 & 8.4 \\
\hline Saudi Arabia & 0.0 & 0.0 & 0.0 & 0.0 & 7.8 \\
\hline Jordan & 0.0 & 0.0 & 0.0 & 1.1 & 1.1 \\
\hline Kuwait & 0.0 & 0.0 & 0.0 & 0.0 & 4.4 \\
\hline Qatar & 0.0 & 0.0 & 0.0 & 0.0 & 2.6 \\
\hline Oman & 0.0 & 0.0 & 0.0 & 0.0 & 2.6 \\
\hline Asia & 85.4 & 139.0 & 190.1 & 179.2 & 347.2 \\
\hline China & 9.1 & 60.0 & 103.6 & 69.8 & 158.1 \\
\hline Japan & 48.8 & 31.3 & 10.3 & 42.4 & 31.5 \\
\hline Taiwan & 5.1 & 5.2 & 3.9 & 7.7 & 7.7 \\
\hline S. Korea & 17.7 & 24.0 & 34.0 & 32.0 & 48.0 \\
\hline Indonesia & 0.0 & 0.0 & 0.0 & 0.0 & 5.2 \\
\hline Malaysia & 0.0 & 0.0 & 0.0 & 0.0 & 5.2 \\
\hline Philippines & 0.0 & 0.0 & 0.0 & 0.0 & 5.2 \\
\hline Thailand & 0.0 & 0.0 & 0.0 & 0.0 & 5.2 \\
\hline India & 4.1 & 17.8 & 34.9 & 25.8 & 72.5 \\
\hline Vietnam & 0.0 & 0.0 & 2.6 & 0.0 & 5.2 \\
\hline Pakistan & 0.5 & 0.8 & 0.8 & 1.4 & 3.4 \\
\hline World & 390.1 & 447.1 & 499.8 & 533.0 & 794.8 \\
\hline
\end{tabular}

a) FSU: Former Soviet Union. 
as reported in literature ${ }^{12}$, the nuclear share in global electricity generation will stay at around $18 \%$ by 2035 . Therefore, even in this scenario, there is still room for a further increase in nuclear capacities after 2035.

Figure 1 shows a comparison between the low and high demand scenarios presented here and scenarios presented by leading international organizations.

The IAEA presents two scenarios: high and low estimates ${ }^{4)}$. In the 2010 version, they estimated that the current net capacity of $372 \mathrm{GW}$ would increase to $546 \mathrm{GW}$ by 2030 in the low estimate and $843 \mathrm{GW}$ in the high estimate. Immediately following the Fukushima Accident in March 2011, the IAEA published a slight downward revision of its latest estimates, where the low estimate would have a capacity of $501 \mathrm{GW}$ and the high estimate of $746 \mathrm{GW}$ by 2030 . As can be seen from Figure 1, the IAEA estimates have similar trends to the low and high demand scenarios presented in this study.

Three scenarios were defined in the IEA's estimates ${ }^{2)}$ : the Current Policies Scenario (CPS), the New Policies Scenario (NPS) and the 450 Scenario. The nuclear capacities are the lowest in the CPS and the highest in the 450 Scenario. As seen in Figure 1, the growth in the generating capacity of the 450 Scenario is similar to that in the high demand scenario presented in this study, and that of the CPS is slightly higher than that in the low demand scenario presented here. It is clear that nuclear generating capacities estimated in the present study based on policies of each country fairly matched with those published by the representative international agencies, and then there should be no discomfort.

\section{(2) Nuclear power output}

The nuclear power output can be estimated by multiplying the generating capacity by assumed capacity factors. For countries that have already been using nuclear energy, the average of the capacity factors over the past five years was used, whereas for newcomer countries, a capacity factor of $80 \%$ was assumed.

From the nuclear power generation estimates calculated above, it is then possible to estimate the demand for NU and UE services in Separative Work Unit (SWU). It should be noted that each demand differs depending on enrichment tails assays: the NU demand is higher and UE services demand is lower with higher tails assays.

There is thus a trade-off relationship between NU and the amount of UE services with respect to tails assays. Tables $\mathbf{2}$ and $\mathbf{3}$ show the NU and UE services demands with high $(0.3 \%)$

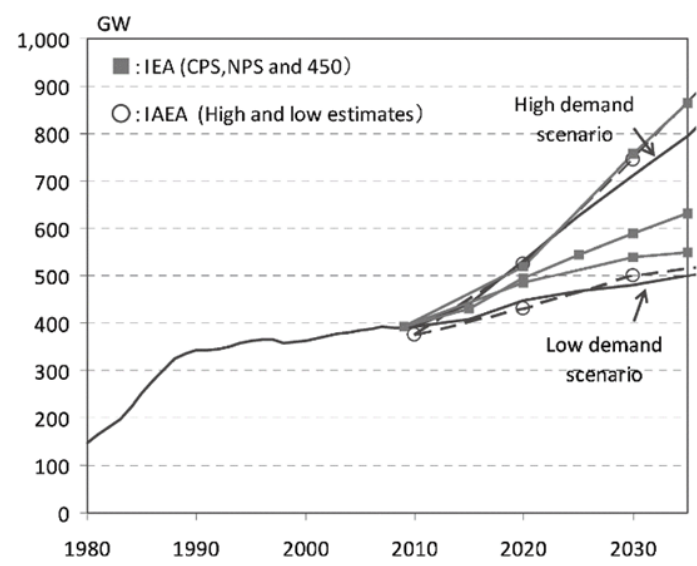

Figure 1 Comparison with nuclear capacity projections by IEA and IAEA 
Table 2 Uranium and uranium enrichment demand (Low demand scenario)

\begin{tabular}{|c|c|c|c|c|c|c|c|c|c|c|c|c|c|c|}
\hline & \multirow{2}{*}{\multicolumn{2}{|c|}{$\begin{array}{c}\text { Electricity } \\
\text { generation } \\
\text { (TWh) }\end{array}$}} & \multirow{2}{*}{\multicolumn{2}{|c|}{$\begin{array}{l}\text { Nuclear power } \\
\text { generation } \\
\text { (TWh) }\end{array}$}} & \multirow{2}{*}{\multicolumn{2}{|c|}{$\begin{array}{l}\text { Nuclear } \\
\text { share }\end{array}$}} & \multicolumn{4}{|c|}{$\underset{(\mathrm{tU})}{\operatorname{Uranium} \text { demand }}$} & \multicolumn{4}{|c|}{$\underset{(\mathrm{tSWU})}{\text { Uranium }} \underset{\mathrm{t} \text { enichment demand }}{ }$} \\
\hline & & & & & & & \multicolumn{2}{|c|}{$0.1 \%$} & \multicolumn{2}{|c|}{$0.3 \%$} & \multicolumn{2}{|c|}{$0.1 \%$} & \multicolumn{2}{|c|}{$0.3 \%$} \\
\hline & 2020 & 2035 & 2020 & 2035 & 2020 & 2035 & 2020 & 2035 & 2020 & 2035 & 2020 & 2035 & 2020 & 2035 \\
\hline USA & 4,673 & 5,261 & 867 & 912 & $19 \%$ & $17 \%$ & 15,109 & 15,886 & 21,326 & 22,423 & 21,127 & 22,214 & 12,421 & 13,060 \\
\hline Canada & 658 & 684 & 81 & 81 & $12 \%$ & $12 \%$ & 1,554 & 1,554 & 1,554 & 1,554 & 0 & 0 & 0 & 0 \\
\hline L. America & 1,812 & 2,749 & 40 & 38 & $2 \%$ & $1 \%$ & 703 & 657 & 992 & 927 & 982 & 918 & 578 & 540 \\
\hline Europe & 4,270 & 4,689 & 887 & 747 & $21 \%$ & $16 \%$ & 15,453 & 13,004 & 21,813 & 18,356 & 21,609 & 18,185 & 12,705 & 10,692 \\
\hline FSU & 1,675 & 1,863 & 276 & 375 & $17 \%$ & $20 \%$ & 4,816 & 6,533 & 6,798 & 9,221 & 6,735 & 9,135 & 3,960 & 5,371 \\
\hline Middle East & 1,140 & 1,589 & 7 & 46 & $1 \%$ & $3 \%$ & 122 & 806 & 172 & 1,137 & 171 & 1,127 & 100 & 662 \\
\hline Africa & 1,023 & 1,930 & 13 & 13 & $1 \%$ & $1 \%$ & 221 & 221 & 312 & 312 & 309 & 309 & 182 & 182 \\
\hline Asia & 10,096 & 13,836 & 1,174 & 1,627 & $12 \%$ & $12 \%$ & 20,447 & 28,341 & 28,861 & 40,004 & 28,592 & 39,631 & 16,810 & 23,300 \\
\hline Oceania & 392 & 514 & 0 & 0 & $0 \%$ & $0 \%$ & 0 & 0 & 0 & 0 & 0 & 0 & 0 & 0 \\
\hline World & 25,737 & 33,115 & 3,346 & 3,838 & $13 \%$ & $12 \%$ & 58,424 & 67,000 & 81,828 & 93,934 & 79,525 & 91,518 & 46,756 & 53,807 \\
\hline
\end{tabular}

Table 3 Uranium and uranium enrichment demand (High demand scenario)

\begin{tabular}{|c|c|c|c|c|c|c|c|c|c|c|c|c|c|c|}
\hline & \multirow{2}{*}{\multicolumn{2}{|c|}{$\begin{array}{l}\text { Electricity } \\
\text { generation } \\
\text { (TWh) }\end{array}$}} & \multirow{2}{*}{\multicolumn{2}{|c|}{$\begin{array}{l}\text { Nuclear power } \\
\text { generation } \\
\text { (TWh) }\end{array}$}} & \multirow{2}{*}{\multicolumn{2}{|c|}{$\begin{array}{l}\text { Nuclear } \\
\text { share }\end{array}$}} & \multicolumn{4}{|c|}{$\underset{(\mathrm{tU})}{\text { Uranium demand }}$} & \multicolumn{4}{|c|}{ Uranium enrichment demand } \\
\hline & & & & & & & \multicolumn{2}{|c|}{$0.1 \%$} & \multicolumn{2}{|c|}{$0.3 \%$} & \multicolumn{2}{|c|}{$0.1 \%$} & \multicolumn{2}{|c|}{$0.3 \%$} \\
\hline & 2020 & 2035 & 2020 & 2035 & 2020 & 2035 & 2020 & 2035 & 2020 & 2035 & 2020 & 2035 & 2020 & 2035 \\
\hline USA & 4,673 & 5,261 & 903 & 1,027 & $19 \%$ & $20 \%$ & 15,736 & 17,895 & 22,212 & 25,259 & 22,005 & 25,024 & 12,937 & 14,712 \\
\hline Canada & 658 & 684 & 88 & 100 & $13 \%$ & $15 \%$ & 1,687 & 1,910 & 1,687 & 1,910 & 0 & 0 & 0 & 0 \\
\hline L. America & 1,812 & 2,749 & 61 & 107 & $3 \%$ & $4 \%$ & 1,064 & 1,868 & 1,501 & 2,636 & 1,487 & 2,611 & 874 & 1,535 \\
\hline Europe & 4,270 & 4,689 & 1,028 & 1,139 & $24 \%$ & $24 \%$ & 17,903 & 19,835 & 25,271 & 27,997 & 25,035 & 27,736 & 14,719 & 16,307 \\
\hline FSU & 1,675 & 1,863 & 389 & 541 & $23 \%$ & $29 \%$ & 6,779 & 9,426 & 9,569 & 13,305 & 9,479 & 13,181 & 5,573 & 7,749 \\
\hline Middle East & 1,140 & 1,589 & 43 & 223 & $4 \%$ & $14 \%$ & 757 & 3,882 & 1,068 & 5,480 & 1,058 & 5,428 & 622 & 3,192 \\
\hline Africa & 1,023 & 1,930 & 13 & 39 & $1 \%$ & $2 \%$ & 221 & 677 & 312 & 955 & 309 & 946 & 182 & 556 \\
\hline Asia & 10,096 & 13,836 & 1,562 & 2,846 & $15 \%$ & $21 \%$ & 27,211 & 49,568 & 38,408 & 69,966 & 38,050 & 69,313 & 22,371 & 40,752 \\
\hline Oceania & 392 & 514 & 0 & 0 & $0 \%$ & $0 \%$ & 0 & 0 & 0 & 0 & 0 & 0 & 0 & 0 \\
\hline World & 25,737 & 33,115 & 4,088 & 6,021 & $16 \%$ & $18 \%$ & 71,357 & 105,059 & 100,029 & 147,508 & 97,424 & 144,240 & 57,279 & 84,804 \\
\hline
\end{tabular}

and low $(0.1 \%)$ tails assays in the high and low demand scenarios, respectively. Here, for simplicity, all nuclear power plants are assumed to be LWRs, with the exception of HWRs in Canada, and the UE services demand is calculated for LWRs with an assumption of UE, the fuel burnup, and a thermal efficiency of $4 \%, 45 \mathrm{GWd} / \mathrm{t}$, and $34.5 \%$, respectively. The tables also show the electricity demand and nuclear share in the Advanced Technologies Scenario presented in literature ${ }^{12}$. As the high and low demand scenarios in this study refer only to nuclear energy demand, rather than to the electricity demand, the nuclear share is higher in the high demand scenario than in the low demand scenario.

\section{Uranium Production Forecast}

With recent increases in the price of uranium, investments in uranium resource development are rapidly expanding. Accordingly, uranium production capacities are expected to drastically improve by 2020. For the future expansion of uranium production capacities, we refer to the evaluation by $\mathrm{OECD}^{8)}$ (Table 4).

A-II in Table 4 shows the forecast based on existing and committed projects, while B-II shows the forecast based on existing, committed, planned, and prospective projects. It is assumed that the committed projects will be launched by 2020 and existing uranium mines will diminish; therefore, the production capacity in 2035 is assumed to be less than that in 2025 . Note that in this forecast, Kazakhstan's production capacity is expected to increase from the current 18,000 tU to 24,000 tU by 2020 , but will decrease to 5,000 to $6,000 \mathrm{tU}$ by 2035 . With 
Table 4 Uranium production forecast $\left(\mathrm{OECD}^{8)}\right)$

\begin{tabular}{|c|c|c|c|c|c|}
\hline & \multirow[b]{3}{*}{2010} & & & \multicolumn{2}{|c|}{ Unit: tU/yr } \\
\hline & & \multicolumn{2}{|c|}{2020} & \multicolumn{2}{|c|}{2035} \\
\hline & & $\begin{array}{c}\text { A-II } \\
\text { (Production } \\
\text { case A) }\end{array}$ & $\begin{array}{c}\text { B-II } \\
\text { (Production } \\
\text { case B) }\end{array}$ & A-II & B-II \\
\hline Argentina & 120 & 500 & 500 & 500 & 500 \\
\hline Australia & 9,700 & 10,100 & 24,200 & 9,800 & 27,600 \\
\hline Brazil & 340 & 2,000 & 2,000 & 2,000 & 2,000 \\
\hline Canada & 16,430 & 17,730 & 19,000 & 17,730 & 19,000 \\
\hline China & 940 & 1,200 & 1,200 & 1,200 & 1,200 \\
\hline Czech & 500 & 50 & 50 & 20 & 20 \\
\hline India & 295 & 980 & 1,200 & 1,000 & 2,000 \\
\hline Iran & 20 & 100 & 100 & 100 & 100 \\
\hline Jordan & 0 & 2,000 & 2,000 & 2,000 & 2,000 \\
\hline Kazakhstan & 18,000 & 24,000 & 24,000 & 5,000 & 6,000 \\
\hline Malawi & 0 & 1,425 & 1,100 & 0 & 0 \\
\hline Mongolia & 0 & 150 & 1,000 & 150 & 1,000 \\
\hline Namibia & 5,000 & 8,000 & 19,000 & 5,000 & 7,500 \\
\hline Niger & 4,000 & 9,500 & 10,500 & 5,000 & 5,000 \\
\hline Pakistan & 65 & 140 & 155 & 140 & 650 \\
\hline Romania & 230 & 350 & 475 & 350 & 630 \\
\hline Russia & 3,520 & 7,600 & 11,990 & 6,800 & 13,400 \\
\hline S. Africa & 4,860 & 4,860 & 6,320 & 4,860 & 6,320 \\
\hline Ukraine & 960 & 810 & 5,500 & 170 & 5,500 \\
\hline USA & 2,900 & 3,800 & 6,600 & 3,100 & 5,600 \\
\hline Uzbekistan & 2,300 & 3,000 & 3,750 & 3,500 & 3,500 \\
\hline World & 70,180 & 98,295 & 140,640 & 68,420 & 109,520 \\
\hline
\end{tabular}

the future growth in global nuclear power generation, irrespective of the scenario, it seems unlikely that uranium production will significantly decrease once it has increased. As diminished existing uranium mines are likely to be compensated for by new uranium resource development after 2020, it is therefore considered that global uranium production will remain stable or increase in the future.

Here, we established two cases, where the uranium production increases until 2020 according to forecast A-II or B-II, and then remains constant until 2035: these are respectively named Uranium Production Cases A and B. In addition, for the high demand scenario in 2035, we also established another case named Production Case $\mathrm{C}$ for when the highest demand occurs and production increases more than in B-II in relation to uranium resource development after 2020. The regional differences between Cases B and C are assumed to be proportional to the differences between Cases A and B.

\section{Outlook for UE Capacities}

Global uranium enrichment facilities currently in operation and in the planning stage are shown in Table $5^{16-19)}$. It is apparent that these facilities are dominated by a few countries, and four companies (including USEC (US), Areva NC (France), Urenco (UK, Germany, and the Netherlands), and Atomenergoprom (Russia)) dominate more than $95 \%$ of the global enrichment capacity.

The Paducah enrichment plant in the US (run by USEC), and the George Besse enrichment plant in France (run by EURODIF, which is a subsidiary of Areva) have played leading role in UE in their respective countries since they were established in 1952 and 1979, respectively. However, as these are inefficient gaseous diffusion plants, they are no longer operating 
Table 5 World's enrichment facilities

\begin{tabular}{|c|c|c|c|c|}
\hline Country & Company & Location & Type & $\begin{array}{l}\text { Capacity, } \\
\text { tSWU/yr }\end{array}$ \\
\hline \multirow[t]{5}{*}{ USA } & \multirow[t]{2}{*}{ USEC } & Paducah & Gaseous diffusion & 11,300 \\
\hline & & Piketon & Centrifugation & 3,800 \\
\hline & Urenco & Eunice & Centrifugation & 3,800 \\
\hline & Areva $\mathrm{NC}$ & Idaho falls & Centrifugation & 6,600 \\
\hline & GE Hitachi Nuclear Energy & Wilmington & Laser & 6,000 \\
\hline Europe & Eurodif (Areva NC etc.) & Georges Besse (Tricastin) & Gaseous diffusion & 10,800 \\
\hline France & Areva NC & Georges Besse II (Tricastin) & Centrifugation & 7,500 \\
\hline \multirow{3}{*}{$\begin{array}{l}\text { UK, Germany and } \\
\text { Netherlands }\end{array}$} & \multirow[t]{3}{*}{ Urenco } & Capenhurst (UK) & Centrifugation & 5,000 \\
\hline & & Almelo (Netherlands) & Centrifugation & 5,000 \\
\hline & & Gronau (Germany) & Centrifugation & 4,200 \\
\hline Japan & JNFL & Rokkasho & Centrifugation & 1,050 \\
\hline \multirow[t]{4}{*}{ Russia } & Atomenergoprom & Angarsk & Centrifugation & 2,500 \\
\hline & Atomenergoprom & Novouralsk & Centrifugation & 13,200 \\
\hline & Atomenergoprom & Zelenogorsk & Centrifugation & 7,800 \\
\hline & Atomenergoprom & Seversk & Centrifugation & 3,700 \\
\hline \multirow[t]{2}{*}{ China } & \multirow[t]{2}{*}{$\mathrm{CNNC}$} & Lanzhou & Centrifugation & 500 \\
\hline & & Hanzhong & Centrifugation & 500 \\
\hline India & Department of Atoic Energy & Ratnahalli & Centrifugation & 25 \\
\hline \multirow[t]{3}{*}{ Iran } & & Natanz & Centrifugation & $\mathrm{n} / \mathrm{a}$ \\
\hline & & Natanz & Centrifugation & \\
\hline & & Qom & Centrifugation & \\
\hline Brazil & INB & Fábrica de Combustivel Nuclear & Centrifugation & 200 \\
\hline Pakistan & & Kahuta & Centrifugation & 5 \\
\hline North Korea & & Nyeongbyeon & Centrifugation & $\mathrm{n} / \mathrm{a}$ \\
\hline
\end{tabular}

at full capacity for economic reasons, and they only operate at around 5,000 tSWU/yr and $3,000 \mathrm{tSWU} / \mathrm{yr}$ out of a capacity of $11,300 \mathrm{tSWU} / \mathrm{yr}$ and 10,800 tSWU/yr, respectively ${ }^{20}$.

Therefore, these companies are currently establishing, or planning to establish, new centrifuge plants to replace the old plants, which is further expected to increase the growing enrichment demand. In France, the George Besse II enrichment plant, which is adjacent to the existing plant, began operation in 2010, and its production capacity is expected to rise to 7,500 tSWU/yr at full operation. In the US, USEC is planning to establish a new centrifuge plant in Piketon in Ohio called the American Centrifuge Plant, and Urenco constructed an enrichment plant in Eunice, New Mexico, that began operating in 2010. Furthermore, Areva NC is planning the construction of a new plant in Eagle Rock, Idaho, and a construction and operation license was acquired in October 2011 from the Nuclear Regulatory Commission (NRC). Moreover, GE-Hitachi is currently constructing an advanced enrichment plant equipped with laser enrichment processes that launched test operations in 2010 .

In Europe, Urenco, which is jointly owned by the UK, Germany, and the Netherlands, has enrichment plants in each of these countries and a total capacity of 14,200 tSWU/yr as of 2011. In addition to the above-mentioned plant in the US, the company plans to expand its capacity up to $18,000 \mathrm{tSWU} / \mathrm{yr}$ by $2015^{21)}$.

Russia has the largest enrichment capacity in the world and owns enrichment plants in Angarsk, Novouralsk, Zelenogorsk, and Seversk that have a total capacity of 27,200 tSWU/yr. In 2007, they established the International Uranium Enrichment Center (IUEC) in Angarsk, as advocated by President Vladimir Putin. Russia aims to prevent UE technologies from being promulgated and also prevent their nuclear fuel supplies from being disrupted by stockpiling enriched uranium under the supervision of the IAEA.

In cooperation with Russia, China has constructed and is operating UE plants in Lanzhou and Hanzhong, each with a capacity of 500 tSWU/yr. In addition, Russian President Dmitry Medvedev and Chinese Premier Wen Jiabao have signed an agreement and contract to build a 
new enrichment plant in 2008 (the 4th plant including those which have already been closed), and if this is completed, China's enrichment capacity will be 1,500 tSWU/yr.

The world's enrichment capacity as of 2011 is estimated at approximately 42,200 tSWU/yr, excluding declines due to economic and other reasons ${ }^{21)}$. In addition, enriched uranium from dismantled nuclear weapons was exported from Russia to the US between 1994 and 2013 under the "Megatons to Megawatts" program, and it is estimated that this amounted to 5,500 tSWU annually. In addition, these covered the UE service demand. In this study, we assume that the uranium supply from dismantled weapons will come to an end by 2020, and that gaseous diffusion plants will be closed in a phased manner, mainly due to economic reasons. Under such circumstances and if the above stated new plants are completed, the world's enrichment capacity will reach 72,300 tSWU by 2020 . This UE capacity is sufficient or not is depends on the amount of UE demand.

If the global enrichment capacity is insufficient in the future and needs to be expanded further, which corresponds to the high demand case and the Enrichment Case C in 2035, the associated regional capacities are assumed to be as follows. In this respect, we firstly restrict the additional capacity expansion to regions (countries) that currently have enrichment facilities and have clear intentions of further expansion. If we exclude Japan, these regions (countries) are the US, Europe, former Soviet Union, and China. Of these, Europe and the US are already expected to construct new plants, as mentioned above, but the nuclear power generation growth will not be as great as that in China and Russia, and may even decline. Consequently, in Europe, where the supply of UE will exceed demand when the new plants that are currently under construction or planning are in operated, it is assumed that enrichment plants will not be further established. Furthermore, in the US, where the demand will slightly exceed the supply in the high demand scenario (as mentioned later), it is assumed only one enrichment plant with a capacity of 6,000 tSWU/yr, which is equivalent to the capacity of the latest laser enrichment plant, will be established. To cover the rest of the increased demand, we assume that enrichment plants will be constructed in Russia and China, where the establishment of no new large facilities have been assumed in Enrichment Case B, in spite of the expected significant increased future demand. Considering the differences between the maturity of domestic technologies, we assume that $70 \%$ of the additional capacity will be constructed in Russia and $30 \%$ in China.

Table 6 shows the assumed capacities of UE plants. Considering all current construction plans, the global enrichment capacity is expected to grow to $72,300 \mathrm{tSWU} / \mathrm{yr}$, as shown in Enrichment Case B. Meanwhile, considering that existing Russian plants currently generate only $18,000 \mathrm{tSWU} / \mathrm{yr}^{20)}$, in the case where the UE services demand is eased, we assume that plants would not be operated in Russia to generate more than the current level, and the global capacity would be 63,100 tSWU/yr (Enrichment Case A). Meanwhile, in the high demand scenario (in 2035), when enrichment facilities become insufficient in relation to the current established plans, we established Enrichment Case C, where Russia and China will expand

Table 6 Enrichment capacity projection

\begin{tabular}{lrrrr} 
& & \multicolumn{2}{c}{ Unit: tSWU/yr } \\
\hline Americas & 5,400 & 20,400 & 20,400 & 26,400 \\
Europe & 18,200 & 21,700 & 21,700 & 21,700 \\
FSU & 18,000 & 18,000 & 27,200 & 35,472 \\
Asia & 2,050 & 3,000 & 3,000 & 6,545 \\
Total & 43,650 & 63,100 & 72,300 & 90,117 \\
\hline
\end{tabular}


their enrichment facilities.

\section{Prices of NU and UE Services}

Although large parts of NU and UE services are procured under long-term contracts, some are purchased at spot markets where prices are disclosed ${ }^{22}$. However, even with long-term contracts, NU and UE services are often traded based on spot prices. Therefore, changes in spot prices are supposed to reflect the trends of overall NU and UE service prices. Past trends in spot prices are shown in Figure 2.

Prior to 2003, the price of NU was very low at around $10 \mathrm{USD} / \mathrm{lb}-\mathrm{U}_{3} \mathrm{O}_{8}$, which reflected the fact that uranium production, including that for military purposes, exceeded commercial uranium demand until the early-90s, and that enriched uranium supply was abundant after the mid-90s because of secondary sources. Thereafter however, nuclear energy was politically promoted in each country due to global environmental concerns, which upwardly revised estimates of nuclear energy generation. Consequently, the price of NU dramatically increased after 2004 and reached nearly $140 \mathrm{USD} / \mathrm{lb}-\mathrm{U}_{3} \mathrm{O}_{8}$ in 2007 , due to the increased societal awareness of the finite nature of natural resources, an understanding that the uranium supply chain depends on a few important facilities, the increased price of primary energies (including crude oil), and intervention by speculators. Although the dramatically increased price entered an adjustment phase, the price stabilized at a higher than previous level and reached approximately $51 \mathrm{USD} / \mathrm{lb}-\mathrm{U}_{3} \mathrm{O}_{8}$ in June 2012.

While the UE service price does not fluctuate as much as that of the price of NU (in the past it fluctuated between 80 USD and 110 USD per kgSWU), it continued to rise after 2005 and temporarily reached 160 USD per kgSWU. It then slowly declined and reached 130 USD per $\mathrm{kgSWU}$ as of June 2012.

As seen in Figure 2, in this study we set two future price scenarios for NU and UE services. First, in the low price case for NU we assumed that although it will not decline to the previous record of $10 \mathrm{USD} / \mathrm{lb}-\mathrm{U}_{3} \mathrm{O}_{8}$, it will remain stable at the lowest price after price adjustment of $40 \mathrm{USD} / \mathrm{lb}-\mathrm{U}_{3} \mathrm{O}_{8}$, because secondary uranium supplies will be terminated. Second, in the high price case for NU, it is estimated to rise again to $140 \mathrm{USD} / \mathrm{lb}-\mathrm{U}_{3} \mathrm{O}_{8}$ (which is the price reached when prices soared in the past).

For the UE service price, in the low price case we estimated that it would drop to 100 USD per $\mathrm{kgSWU}$, which is the price reached prior to the sudden rise, but in the high price case we estimated it would rise to $160 \mathrm{USD}$ per $\mathrm{kgSWU}$, which is the price reached when prices soared.
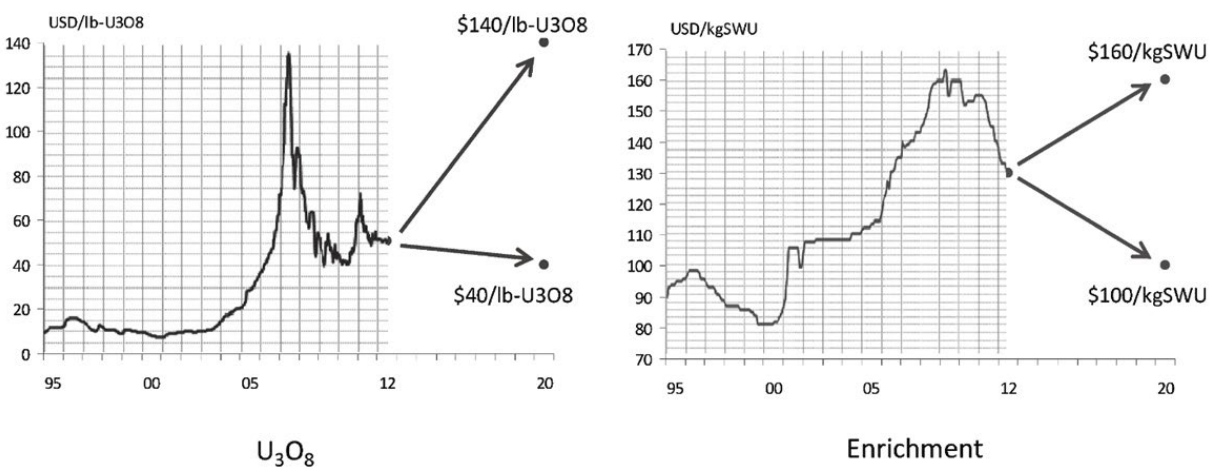

Figure $2 \mathrm{U}_{3} \mathrm{O}_{8}$ and uranium enrichment spot prices ${ }^{22)}$ 


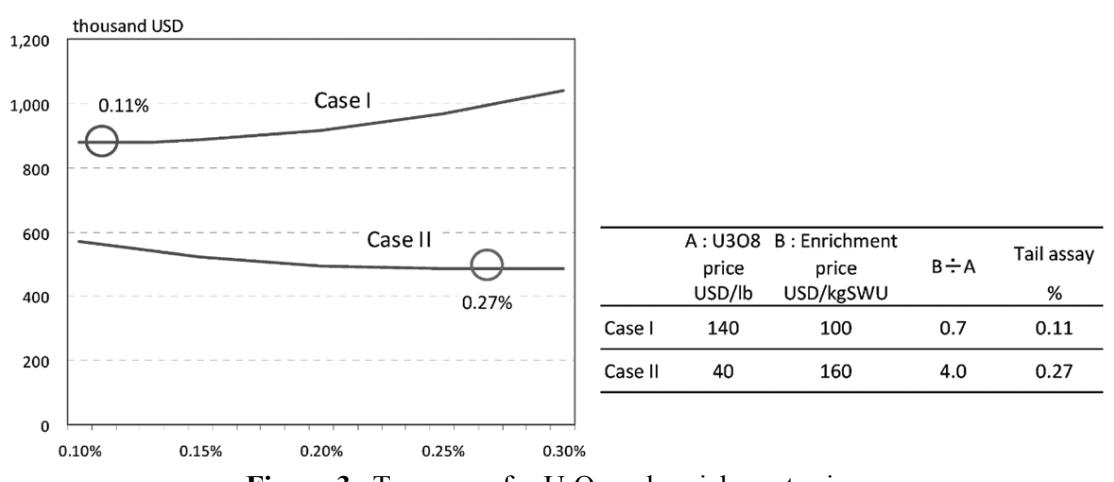

Figure 3 Two cases for $\mathrm{U}_{3} \mathrm{O}_{8}$ and enrichment prices

The demand for NU and UE services have a trade-off relationship in relation to tails assays. Therefore, when the NU unit price and UE service unit price are determined, the total price (the NU purchase price and the UE service price) is calculated based on their demand amounts according to tails assays, and the optimum tails assay is calculated using the condition that provides the lowest total cost. Therefore, to estimate the prices of NU and UE services in 2020 and 2035, we established two representative price cases: Price Case I and Price Case II. In Price Case 1, NU is estimated to be as high at $140 \mathrm{USD} / \mathrm{lb}-\mathrm{U}_{3} \mathrm{O}_{8}$ and UE services as 100 USD per $\mathrm{kgSWU}$, whereas in Price Case 2, NU is estimated to be as low as $40 \mathrm{USD} / \mathrm{lb}-\mathrm{U}_{3} \mathrm{O}_{8}$ and UE services as 160 USD per $\mathrm{kgSWU}$. These cases provide an estimate that optimum tails assays are $0.11 \%$ and $0.27 \%$, respectively (Figure 3). In this study, these two price cases were set as the upper and lower tails assays limits, and the future demand amounts of NU and UE services were then calculated. The optimum tails assay is determined by the ratio of the UE service price (USD/kg-SWU) to the NU price (USD/lb- $\mathrm{U}_{3} \mathrm{O}_{8}$ ), which is 0.7 and 4.0 for Price Case I and II, respectively.

\section{Method used to Estimate Trade Flows}

Based on the above assumptions, we made an estimate for NU and EU trade flows in 2020 and 2035.

Global trade flow estimations of oil products or natural gas are usually conducted using cost optimization methods ${ }^{23,24}$. For example, using linear programming as an optimization method, costs of production, shipping, transportation, and refining of petroleum and natural gas are calculated for every country in the world and the optimal supply-demand balance where the total cost takes the minimal value is obtained to make trade flow.

In the above estimations, selection of the LNG supplier is determined by the balance between the local production costs and those related to transportation to the destination. In the case of nuclear power, however, unlike oil and natural gas, it is practically impossible to obtain accurate data on costs relating to shipment, transportation, conversion, enrichment, reconversion, and other processes, as most of them are undisclosed. At the same time, as often pointed out, because the energy density of uranium fuel is far higher than that of fossil fuels, costs related to its transportation are proportionally low. For example, one reference ${ }^{25}$ estimated the transportation cost of uranium hexafluoride from Europe to an enrichment plant in Russia as 1.5 USD per $\mathrm{kg}$, which is almost equivalent to $1 / 100$ of LNG's transportation cost from Indonesia to Japan $(0.5 \mathrm{USD} / \mathrm{MMBtu})^{26)}$, if costs per unit electricity generation are compared. However, the cost per unit mass for intercontinental transportation of spent nuclear fuels is much higher at 200 
$\mathrm{USD} / \mathrm{kg}^{27)}$, which suggests that nuclear-related transportation costs are largely related to safety measures and regulations rather than distance.

The actual procurement of uranium fuel by power utilities is mainly based on long-term contracts. When selecting a supplier, the purchasers usually consider the price for the fuel itself, past contracts, various rights and interests, and the political partnership between the two countries, and the transportation costs are not the most important factor considered. Therefore, unlike conducting analyzes of petroleum product trade flows, calculating trade balances based on differences in transportation costs is not appropriate when analyzing nuclear fuels.

Therefore, this study uses actual recent trade flow data (i.e., the share of NU and UE services supplied to a country from various countries), and estimates future trade flows by revising the data according to future conditions. In other words, we assumed that past trade flows contain various information about political and geopolitical influences, existing contracts, rights and interests, and other important factors, and that these situations will not change greatly in the future from those in 2009 because of the rigidity associated with long-term contracts. To be more specific, we calculated the demand for NU and UE services in 2020 and 2035 in each region with the assumption of tails assays for each case (as described later). On this basis, and supposing that global supply meets global demand, we assumed that the supply will decrease with a uniform decline in operation rates among regions, when it has a capacity lower than Production and Enrichment Case A. When the supply lies between that of Cases A and B, we set capacities assuming that the proportion between the two cases was uniform for each region. Furthermore, when it exceeds Case B, we calculated the supply for each region by using Case $\mathrm{C}$, as previously mentioned.

In the past, global uranium production has never exceeded $90 \%$ of its production capacity, and production has been between $75 \%$ to $84 \%$ since $2003^{8)}$. We assumed here that the actual uranium production cap was $80 \%$ of the uranium production capacity, as shown in Table 4 .

Using these assumptions for the demand by region for NU and UE services as boundary conditions, we evaluated a flow that minimizes the following objective function $x$,

$$
\chi=\sum_{i, j}\left(x_{i, j}-x_{i, j}^{0}\right)^{2}
$$

where $x_{i, j}^{0}$ and $x_{i, j}$ indicate the share of import from region $\mathrm{j}$ to region $\mathrm{i}$ in the entire import to $\mathrm{i}$ in 2009 (actual value), and its future estimates for the years 2020 or 2035, respectively.

Actual trades in 2009 were calculated by modifying data ${ }^{28)}$, where the supply of NU, uranium conversion and UE services, and fuel fabrication services for PWRs and BWRs is estimated by region and by company. Tables $\mathbf{7}$ and $\mathbf{8}$ show aggregated inter-regional trade of NU and UE services for 2009.

It is of note that, in line with actual trade, the trade flow of NU refers to the flow from the uranium production country to the country where the final fuel is consumed, rather than to the country where uranium is enriched.

The actual data from 2009 include the enrichment service flow from Europe to the US, and this shows that uranium enriched in Areva's plant in Europe is consumed in the US. However, as can be seen from Table 5, Areva is currently constructing an enrichment plant in the US for use in the US market. Therefore, in this study, we assumed the future operation and launch of this plant, and thus the UE service supply from Europe to the US is not included in the future estimation. It was not possible to obtain the historical input share of the Middle East for use in equation (1) because there has been no actual nuclear power generation or production/supply of NU. Therefore, we assumed that if the Middle East exports NU, the destination will be Asia or 
Table 7 Uranium trade (2009)

\begin{tabular}{|c|c|c|c|c|c|c|c|c|c|c|c|}
\hline From: $\quad$ To: & USA & Canada & L. America & Europe & FSU & Middle East & Africa & Asia & Oceania & Unknown & World \\
\hline USA & 1,921 & & & & & & & & & & 1,921 \\
\hline Canada & 3,867 & 1,600 & 21 & 3,664 & 19 & & & 1,819 & & 1,913 & 12,904 \\
\hline L. America & & & 330 & & & & & & & & 330 \\
\hline Europe & & & & 1,174 & & & & & & & 1,174 \\
\hline FSU & 3,789 & & 62 & 8,480 & 8,856 & & 131 & 12,013 & & 5,466 & 38,796 \\
\hline Middle East & & & & & & & & & & & 0 \\
\hline Africa & 1,425 & & 52 & 2,188 & 62 & & & 2,904 & & 3,315 & 9,946 \\
\hline Asia & & & & & & & & 1,274 & & & 1,274 \\
\hline Oceania & 522 & & 47 & 2,048 & 61 & & & 3,924 & & 2,900 & 9,503 \\
\hline Unknown & 51 & & 10 & 883 & 13 & & & 2,496 & & 101 & 3,554 \\
\hline World & 11,576 & 1,600 & 522 & 18,438 & 9,011 & & 131 & 24,431 & & 13,695 & 79,402 \\
\hline
\end{tabular}

Table 8 Enrichment trade (2009)

\begin{tabular}{|c|c|c|c|c|c|c|c|c|c|c|c|}
\hline \multicolumn{12}{|c|}{ Unit: tSWU } \\
\hline From: & USA & Canada & L. America & Europe & FSU & Middle East & Africa & Asia & Oceania & Unknown & World \\
\hline USA & 7,063 & & & 909 & & & & 4,536 & & 1,219 & 13,727 \\
\hline Canada & & & & & & & & & & & 0 \\
\hline L. America & & & 236 & & & & & & & & 236 \\
\hline Europe & 5,133 & & 160 & 16,875 & & & & 2,958 & & 1,146 & 26,272 \\
\hline FSU & 5,500 & & 2 & 4,213 & 5,540 & & 94 & 1,078 & & 4,899 & 21,326 \\
\hline Middle East & & & & & & & & & & & 0 \\
\hline Africa & & & & & & & & & & & 0 \\
\hline Asia & & & & & & & & 955 & & & 955 \\
\hline Oceania & & & & & & & & & & & 0 \\
\hline World & 17,696 & 0 & 398 & 21,997 & 5,540 & 0 & 94 & 9,527 & 0 & 7,264 & 62,516 \\
\hline
\end{tabular}

Europe, where the demand is high. For $x_{i, j}^{0}$ we used the production in the Middle East divided by the demand in each region, and for the case where the Middle East imports NU, we assumed that the source regions would be the former Soviet Union, Africa, and Oceania, where resources are abundant. If the Middle East imported UE services, we assumed that the source regions would be the former Soviet Union and Europe, which have greater export capacities. We used values of $1 / 3$ for NU and $1 / 2$ for UE services as $x_{i, j}^{0}$ in equation (1), respectively.

In these estimates, the cost of transportation between regions was not considered to be an influential factor when calculating future trade flow. This is because, as stated above, the impact of transportation costs is considered to be relatively low when determining the uranium fuel flow. To evaluate the uncertainty of the estimates, we also estimated a case (as a reference) where trade flow is determined based on transportation cost between regions. In this case, we firstly set the supply and demand by region, as described above, and then calculated the flows of trade across the world where transportation costs are the lowest, assuming (for simplicity) that transportation costs would proportionally increase with the distance between regions. We set the distance between regions by referring to Ref. 29, which is widely used for oil tankers. To simplify this estimation, we used the distance between representative ports, such as St. Petersburg and Hamburg, for each region. It is of note that ports used for the actual shipping and receiving uranium are sometimes other neighboring ports. As we considered that the former Soviet Union requires land transportation to ports in addition to marine transportation, we added the distance from Kazakhstan to St. Petersburg for NU and that from Angarsk to St. Petersburg for UE. In the case of oil, for example, land transportation is more expensive than marine transportation, but in the case of uranium, as the transportation lot size is small, 
marine transportation is relatively costly. In this study, we assumed that both land and marine transportation costs for uranium would work out the same.

We also assumed (as discussed later) that the US and Europe would use at least $50 \%$ of the output from newly established UE plants in US and EU to cover the demand of their own regions.

\section{Scenario Setting}

Table 9 shows the scenario setting. We estimated the supply and demand balance in 2020 and 2035 and calculated trade flows for the low and high demand scenarios.

As described in detail in the following section, in both scenarios for 2020 and in the low demand scenario for 2035, the demand for enriched uranium can be met with existing uranium resource development projects and enrichment plant construction plans.

In the low demand scenario in 2020, in particular, both the supply and demand balance of NU and UE services will be significantly eased. In this case, we assumed the minimum cases, Production Case A and Enrichment Case A, for the NU production capacity and the UE capacity, respectively. However, even in these cases, the supply and demand balance is eased and facilities will not be required to work at full operation. In contrast, for the low demand scenario (2035) and high demand scenario (2020), we assumed the planned expansion of Case B's estimation of capacities. In the high demand scenario in 2035, the demand for NU and UE services cannot be satisfied by the existing plan only; therefore, in these cases, we established Case $\mathrm{C}$, where both the uranium production capacity and enrichment capacity are additionally expanded to a greater extent than previously planned. We then defined the tails assay for each case based on the supply and demand status of NU and UE services. The details of the assumptions are described in each subsection in Chapter III. For the high demand scenario in 2035, we made a separate estimation for the reference case (where supply and demand regions are matched based on transportation costs) for comparison purposes.

\section{Usability of Reprocessed Uranium}

Reprocessed uranium is that generated when spent fuel is reprocessed, and it usually contains around $1 \% \mathrm{U} 235$, which is higher than $0.72 \%$ for NU. By enriching and using reprocessed uranium, it is possible to reduce the demand for NU.

According to Ref. 30, an accumulated amount of 6,350 MOX fuel assemblies, which was generated by reprocessing spent fuel, had been loaded into 58 reactors in France, Germany, Switzerland, Belgium, the US, and other countries by the end of 2008. When we calculate the power output with MOX fuel using actual values of the loading rate estimated in Ref. 30, and supposing a facility capacity factor of $80 \%$, it provides 83 TWh per year, which is about $3 \%$ of the global nuclear power generation in 2009.

Because producing fuel using reprocessed uranium costs more than that by enriching NU, as more reprocessed uranium is used, costs are higher in most cases. However, if the price of NU

Table 9 Scenario setting

\begin{tabular}{ccccc}
\hline Scenario & & $\begin{array}{c}\text { Uranium } \\
\text { production } \\
\text { capacity }\end{array}$ & $\begin{array}{c}\text { Enrichment } \\
\text { capacity }\end{array}$ & $\begin{array}{c}\text { Tail assay } \\
\%\end{array}$ \\
\hline Low demand & 2020 & Case A & Case A & 0.22 \\
& 2035 & Case B & Case B & 0.27 \\
High demand & 2020 & Case B & Case B & 0.27 \\
& 2035 & Case C & Case C & 0.27 \\
\hline
\end{tabular}


costs more than $150 \mathrm{USD} / \mathrm{lb}-\mathrm{U}_{3} \mathrm{O}_{8}$, expanding the use of reprocessed uranium would cost the same as using NU ${ }^{11}$. As of 2010, the reprocessing facilities at Sellafield (UK), la Hague (France), and Chelyabinsk (Russia) have capacities of 4,600 tHM/yr. New construction is planned for a RT-2 reprocessing facility (1,000 to $1,500 \mathrm{tU} / \mathrm{yr})$ in Russia, but it is currently suspended due to economic reasons ${ }^{17)}$. If these facilities other than RT-2 run in a stable manner at an operation rate of $80 \%$, for example, about $3,700 \mathrm{tU}$ of reprocessed uranium will be available at the most. This is equivalent to approximately $3 \%$ to $6 \%$ of the NU demand indicated in Tables 2 and 3 (in 2020 and 2035) and the required production amount will thus decrease by this amount. In addition, as the $\mathrm{U} 235$ assay of reprocessed uranium is around $1 \%$ and that of $\mathrm{NU}$ is $0.72 \%$, the demand for UE services would decrease due to the difference. However, the decline would be small compared to the decline in the demand for NU. In this study, we did not explicitly consider the use of reprocessed uranium, and if this is taken into consideration, the demand for NU may slightly decrease. Although the impact is not significant with reference to the current reprocessing facilities only, it would be more significant if a new large-scale construction of reprocessing facility was planned responding to a trend of the reprocessed and natural uranium costs.

\section{Results and Discussion}

\section{Trade flows for the Low Demand Scenario}

Figure 4 presents estimates of global NU and UE services using the low demand scenario.

\section{(1) Year 2020}

The demands for NU in 2020 are 59,232 tU and 76,978 tU, and those for UE services are 76,372 tSWU and 49,685 tSWU in Price Cases I and II (tails assays are $0.11 \%$ and $0.27 \%$ ), respectively.

The production capacity of NU (multiplying operating rate of 0.8 ) is between 78,636 and 112,512 tU. In Case A, where no new project proceeds, if any price cases (tails assays) are applied, the demand for NU can be satisfied by the production of 78,636 tU. However, although in Price Case I the demand for UE services slightly exceeds the capacity (Enrichment Case B), which includes the capacity of enrichment facilities under construction and in the planning
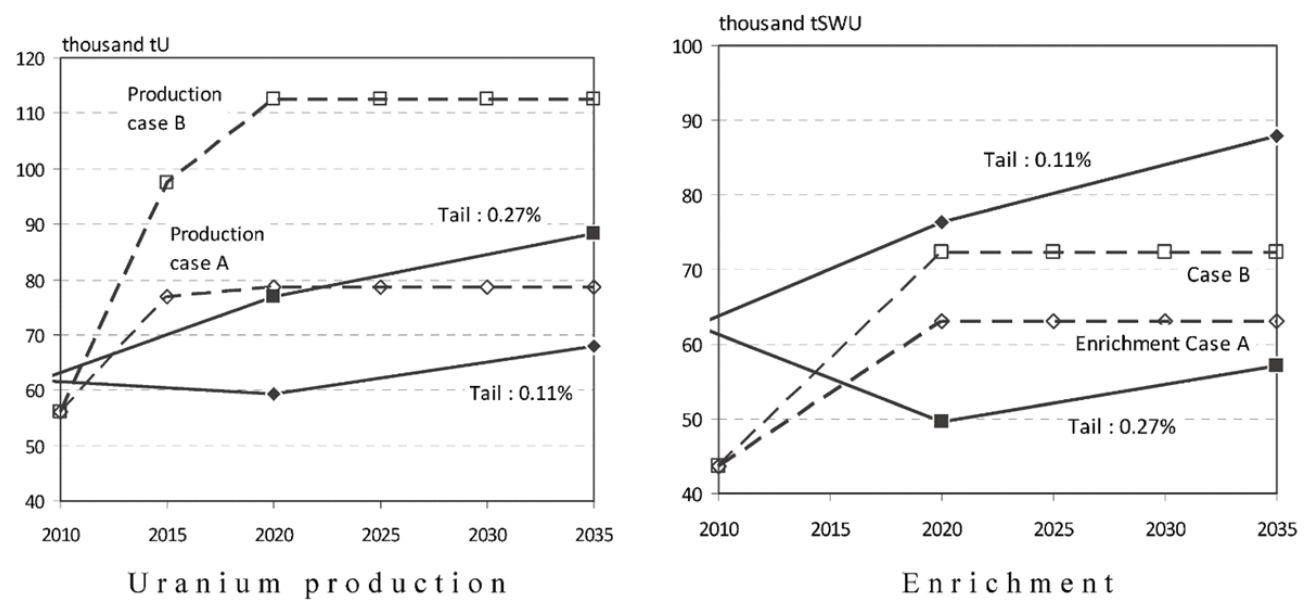

Figure 4 Uranium production and enrichment projections (Low demand scenario) 
phase, it will significantly fall below the capacity in Price Case II.

Considering these, it is highly likely in the low demand scenario that the supply and demand balance of NU, in particular, will be significantly eased, and the price will fall far below 40 $\mathrm{USD} / \mathrm{lb}-\mathrm{U}_{3} \mathrm{O}_{8}$, which is the assumption for Case II. In addition, as the supply capacity of NU becomes excessive, it will be enriched at high tails assays. As a result, the price of UE services is also likely to decline, due to easing of the supply and demand balance. Under such circumstances, it is also likely that NU resource development projects will stagnate, and that enrichment facilities that are currently in the planning phase on a large scale (particularly in the US) will be delayed or cancelled.

In this case with the lowest tails assays, UE services will surpass the estimated facility capacity, and the demand for NU will fall significantly below supply. As such a price could not be accepted by the market, it is supposed that tails assays will remain at a high level. Here we obtained a tails assay value for a case where the NU demand and the demand for UE services have the same ratio in Production Case A and Enrichment Case A (0.88 times: their supply amounts are less than the lowest supply capacities because their supply and demand balances are eased), which provides a tails assay of $0.22 \%$. This occurs when the UE service price in $\mathrm{USD} / \mathrm{kg}-\mathrm{SWU}$ is about 2.5 times that of $\mathrm{NU}$ in $\mathrm{USD} / \mathrm{lb}-\mathrm{U}_{3} \mathrm{O}_{8}$, and the UE service price is relatively high. If we suppose that the NU price falls below $40 \mathrm{USD} / \mathrm{lb}-\mathrm{U}_{3} \mathrm{O}_{8}$, as stated above, the UE service price will drop below $100 \mathrm{USD} / \mathrm{kg}$-SWU. Therefore, this case would also cause the UE price to significantly drop from its current price of $130 \mathrm{USD} / \mathrm{kg}-\mathrm{SWU}$.

The projected trade flows are shown in Tables 10 and 11. Asia, where the demands significantly increase, will be supplied NU from the former Soviet Union (Russia, Kazakhstan, and

Table 10 Uranium trade (Low demand scenario: 2020)

\begin{tabular}{|c|c|c|c|c|c|c|c|c|c|c|}
\hline & & & & & & & & & & Unit: $t U$ \\
\hline From: $\quad$ To: & USA & Canada & L. America & Europe & FSU & Middle East & Africa & Asia & Oceania & World \\
\hline USA & 2,690 & & & & & & & & & 2,690 \\
\hline Canada & 5,855 & 1,554 & & 3,752 & & & & 1,389 & & 12,549 \\
\hline L. America & 542 & & 840 & & & & & 387 & & 1,769 \\
\hline Europe & & & & 283 & & & & & & 283 \\
\hline FSU & 3,596 & & & 6,580 & 5,760 & & 264 & 8,863 & & 25,063 \\
\hline Middle East & & & & 702 & & 146 & & 638 & & 1,486 \\
\hline Africa & 4,590 & & & 4,916 & & & & 7,328 & & 16,835 \\
\hline Asia & & & & & & & & 1,748 & & 1,748 \\
\hline Oceania & 798 & & & 2,249 & & & & 4,102 & & 7,149 \\
\hline World & 18,070 & 1,554 & 840 & 18,483 & 5,760 & 146 & 264 & 24,455 & 0 & 69,573 \\
\hline
\end{tabular}

Table 11 Enrichment trade (Low demand scenario: 2020)

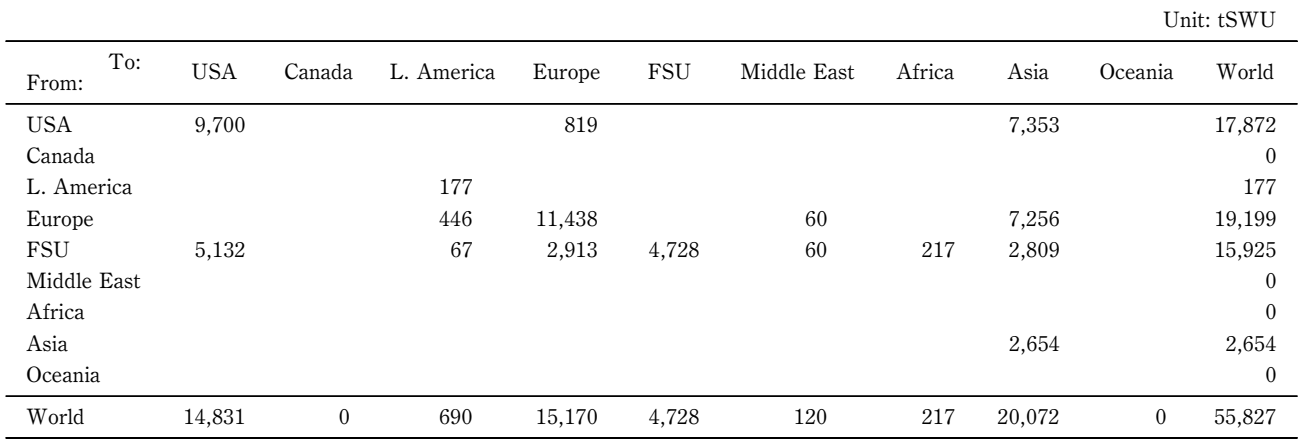


other countries), Africa, and Australia. Europe will be supplied from the former Soviet Union and Africa, and the US will be supplied from Canada. The balance of supply and demand of NU will be eased by 2020, and particularly in the low demand scenario, no large-scale project will be implemented other than those that are already fixed. In such a case, the production amount will not increase from the current level in Australia, and there will be an increase in the export from the former Soviet Union and Africa to other regions.

In addition, if an amount of 2,000 tU is produced in Jordan as planned, it will far exceed production in the Middle East, and they will need to export uranium to other regions (Europe, Asia, and other regions).

Even in this low demand scenario, the UE service demand is supposed to increase, especially in Asia. Consequently, the import of UE services from Europe, Russia, and the US to Asia will increase towards 2020. However, if this region (especially China) tries to substantially expand the enrichment capacity to satisfy the UE service demand in the region, there is a concern that the global supply of UE services may be excessive. It is thus difficult for Asian countries to substantially lower their dependence on imported enrichment services.

\section{(2) Year 2035}

The demands for NU in 2035 are 67,931 tU and 88,352 $\mathrm{tU}$, and those for UE services are $87,890 \mathrm{tSWU}$ and 57,178 tSWU in Price Cases I and II, respectively (with tails assays of $0.11 \%$ and $0.27 \%$ ).

For the NU production capacity in 2035, the production capacity of A-II and B-II in 2020 is assumed to be retained in Production Cases A and B, as stated above, which is 78,636 tU and $112,512 \mathrm{tU}$, respectively. If there is no increased demand, there will be a decline in the production capacity. The production capacity multiplied by an availability of $80 \%$ will then drop to $54,736 \mathrm{tU}$ of A-II in 2035 at the lowest, and this would occur in a case where the NU price declines and remains substantially low due to a reason such as secondary supply.

In the low demand scenario, the NU demand of 67,000 tU in 2035 will not exceed the lower limit $(78,636 \mathrm{tU})$ of the production capacity in Price Case I. In addition, for Price Case II, the NU demand of 93,934 tU will be slightly above the lower limit. This means that whatever the tails assay amount, the supply of NU will remain excessive. Whereas, although the demand for UE services will fall far below Enrichment Case A in Price Case II, it will be far above that of Enrichment Case B in Price Case I. This shows that tails assays will not significantly decline in the low demand scenario, even in 2035, and that it will remain at high level. If a same ratio is assumed with respect to the supply capacity to the cases where all the projects currently in the planning stage are implemented (Production Case B and Enrichment Case B), both demands will remain at $79 \%$ of the supply capacities, and tails assays will be around $0.27 \%$, which is equivalent to that in Price Case II.

If enrichment plants that are currently in the planning stage begin operation by 2035 , the supply and demand relation between NU and UE projects will not become tight even in 2035, and instead the production amount will decline with respect to the easing of the supply and demand balance. In such a case, it will be difficult to construct any further enrichment plants by 2035 . Furthermore, it is supposed that the prices of NU and enrichment service will fall to easing of the supply and demand balance. The $0.27 \%$ tails assay indicates that the optimal ratio of the UE service price in USD/kg-SWU to the NU price in USD $/ \mathrm{lb}-\mathrm{U}_{3} \mathrm{O}_{8}$ is about 4:1. In this case, even if the UE price remains at $130 \mathrm{USD} / \mathrm{kg}-\mathrm{SWU}$, which is the same level as the current price, there will be a significant drop in the NU price to about $30 \mathrm{USD} / \mathrm{lb}-\mathrm{U}_{3} \mathrm{O}_{8}$. This means that in the low demand scenario, even if only the existing uranium resource development plans and enrichment facility constructions that are currently in the planning stage are implemented, 
the supply will remain excessive until 2035. In addition, it is supposed that prices will drop due to easing of the supply and demand balance. Therefore, it is highly likely in this case that both projects currently in the planning stage will not only be delayed but will be called off by 2035 .

The estimated results for a tails assay of $0.27 \%$ are shown in Tables 12 and $\mathbf{1 3}$ and in Figures 5 and 6.

In this case, $70 \%$ of the increased demand from 2020 to 2035 for global NU will come from Asia. This increased demand will mainly be covered by supplies from Africa and Australia. The demand in Europe will decrease from 2020, which will slightly reduce the amount traded from the former Soviet Union and Africa.

In this scenario, as the tails assay is supposed to increase from that in 2020 , there will be a relatively small increase in the UE service demand. Although the demand in Asia will increase, that in the US and Europe will decrease. In particular, there will be a significant decline in the demand in Europe, and the export of UE services from Europe and Russia to Asia will increase.

\section{High Demand Scenario}

Estimates of global NU and UE services in the high demand scenario are shown in Figure 7.

\section{(1) Year 2020}

The demands for NU in 2020 in the high demand scenario are 72,348 $\mathrm{tU}$ and 94,086 tU, and those for UE services are 93,561 tSWU and 60,868 tSWU in Price Cases I and II (tails assays are $0.11 \%$ and $0.27 \%$ ), respectively.

Table 12 Uranium trade (Low demand scenario: 2035)

\begin{tabular}{|c|c|c|c|c|c|c|c|c|c|c|}
\hline & & & & & & & & & & Unit: $\mathrm{tU}$ \\
\hline From: $\quad$ To: & USA & Canada & L. America & Europe & FSU & Middle East & Africa & Asia & Oceania & World \\
\hline USA & 3,703 & & & & & & & & & 3,703 \\
\hline Canada & 6,808 & 1,554 & & 3,583 & & & & 2,540 & & 14,485 \\
\hline L. America & 465 & & 874 & & & & & 661 & & 2,000 \\
\hline Europe & & & & 350 & & & & & & 350 \\
\hline FSU & 3,890 & & & 6,473 & 8,695 & 0 & 294 & 11,303 & & 30,655 \\
\hline Middle East & & & & 606 & & 1,072 & & 2 & & 1,680 \\
\hline Africa & 5,074 & & & 3,946 & & 0 & & 13,117 & & 22,138 \\
\hline Asia & & & & & & & & 2,233 & & 2,233 \\
\hline Oceania & 1,202 & & & 2,351 & & 0 & & 7,866 & & 11,419 \\
\hline World & 21,144 & 1,554 & 874 & 17,309 & 8,695 & 1,072 & 294 & 37,721 & 0 & 88,662 \\
\hline
\end{tabular}

Table 13 Enrichment trade (High demand scenario: 2035)

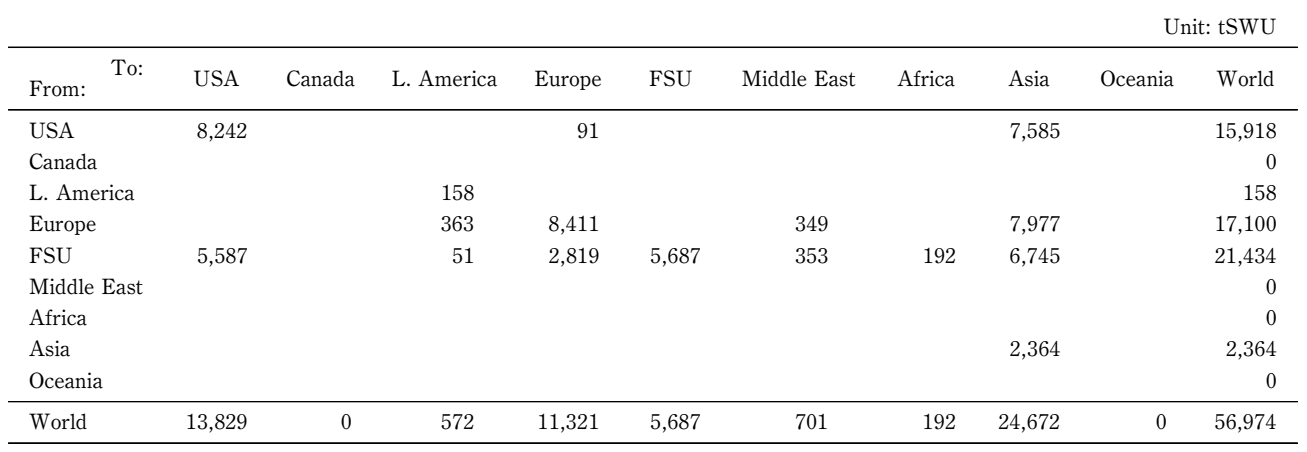




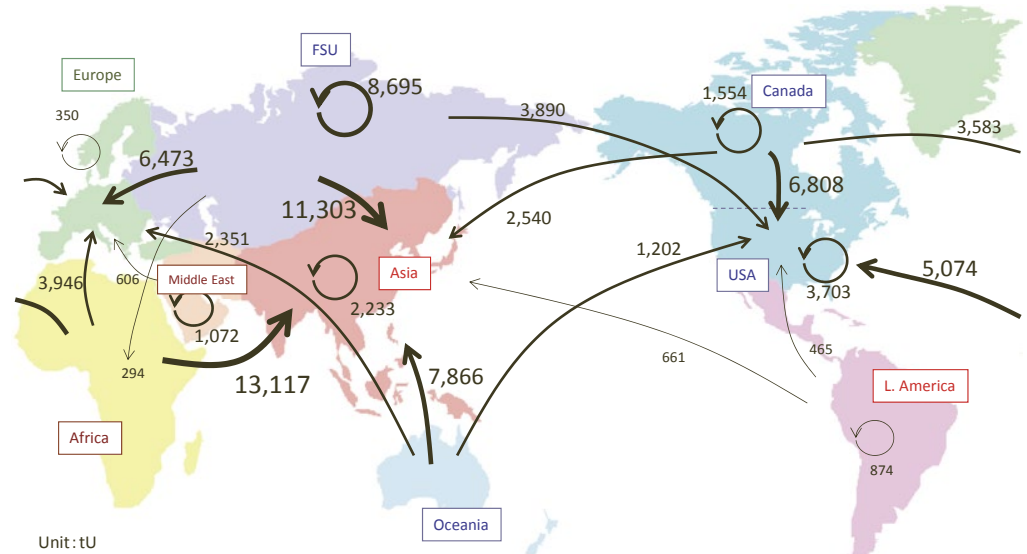

Figure 5 Uranium trade (Low demand scenario: 2035)

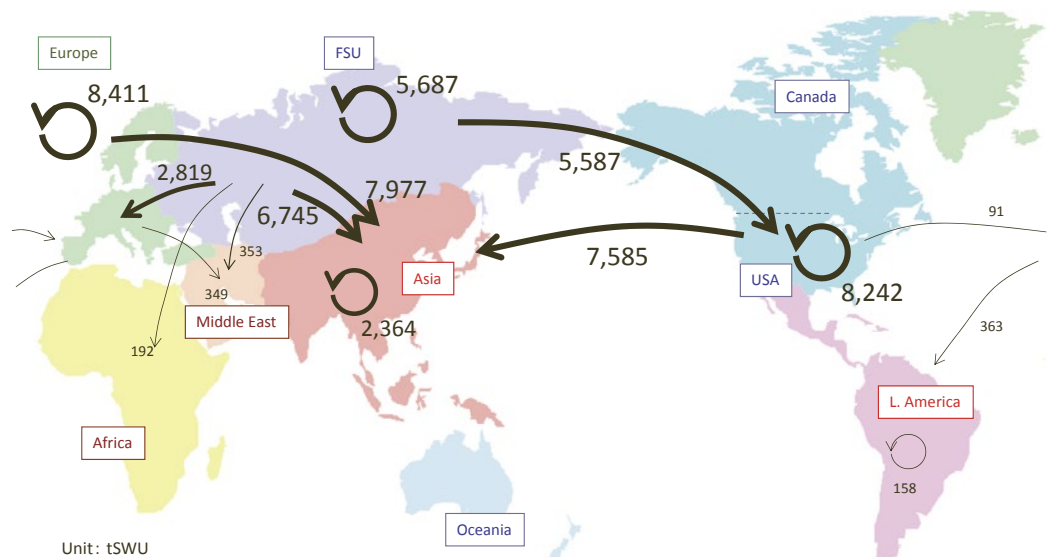

Figure 6 Enrichment trade (Low demand scenario: 2035)
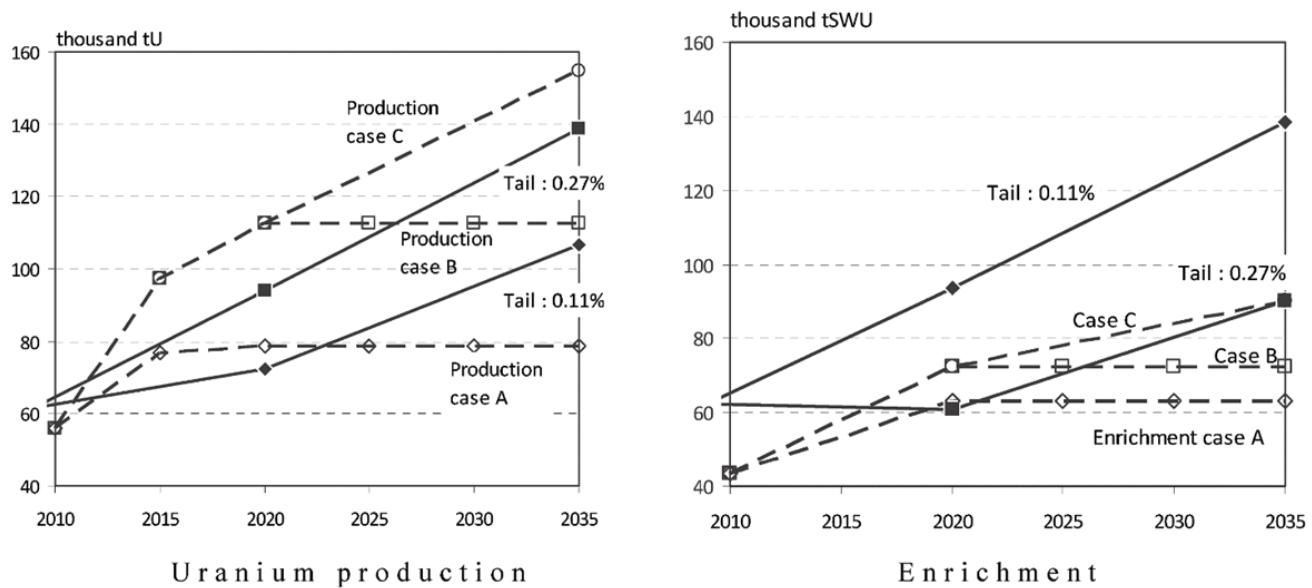

Figure 7 Uranium production and enrichment projections (High demand scenario) 
The demand for NU will fall below that in Production Case B, even with Price Case II where the tails assay is high. This means that if uranium resource development projects that are currently in the planning stage are implemented, the supply will exceed the demand, even in the high demand scenario. The demand for UE services will be at around the same level as in Enrichment Case A with Price Case II where the tails assay is high, and it will far exceed that of Enrichment Case B with Price Case I, where the tails assay is low. This means that the supply and demand for NU will be relatively eased compared to that of UE services, and in this case, therefore, it is supposed that the tails assay will remain at a high level.

If we suppose that the ratio of both NU production and UE services will be the same with respect to the supply capacities for Production Case B and Enrichment Case B, where all projects currently in the planning stages are implemented, demands will be $84 \%(94,400 \mathrm{tU}$ and 60,662 tSWU) of the capacity, and tails assay will again be around $0.27 \%$, which is at a similar level to that in Price Case II.

If we suppose that all new projects currently in the planning stages have been planned to provide reasonable profits at the current price level, the demand growth to attain levels of Production Case B and Enrichment Case B, where implementation of the new projects are taken into account, will be that sustains the current price level. If demand falls lower than this, it is supposed that only low-cost projects will be implemented and uranium prices will decline. As in the case presented in the previous section, the $0.27 \%$ tails assay in this case indicates that the optimal ratio between the UE service price in USD/kg-SWU to the NU price in USD/lb- $\mathrm{U}_{3} \mathrm{O}_{8}$ is about $4: 1$. Even if the UE price remains at the current level of $130 \mathrm{USD} / \mathrm{kg}-\mathrm{SWU}$, the NU price will drop significantly to about $30 \mathrm{USD} / \mathrm{lb}-\mathrm{U}_{3} \mathrm{O}_{8}$. This means that even in the high demand scenario, if we consider the operation launch of the currently planned UE plants, it is highly likely that the supply and demand balance of NU will be eased, and resource development investment will decline.

The estimated results of trade flows are presented in Tables 14 and 15.

In response to the increased demand, the trade in NU will increase more than in the low demand scenario. In particular, exports from the former Soviet Union, Africa, and Australia to Asia will increase. With an increase in the global uranium demand, it is expected that Australia will become increasingly important as a uranium producing country, because of its large uranium resources. However, the NU production capability of Australia in 2020 is not so large.

The UE service demand will also increase, particularly in Asia. In this respect, imports from North America, Russia, and Europe will increase. Compared to the current situation, import expansion will be significant, particularly from North America where many new enrichment plants are being constructed, and from Russia, which has a significant capacity margin. However, as stated above, even in this case, no further enrichment facilities will be required, other

Table 14 Uranium trade (High demand scenario: 2020)

\begin{tabular}{|c|c|c|c|c|c|c|c|c|c|c|}
\hline From: $\quad$ To: & USA & Canada & L. America & Europe & FSU & Middle East & Africa & Asia & Oceania & World \\
\hline USA & 4,082 & & & & & & & & & 4,082 \\
\hline Canada & 6,450 & 1,687 & & 4,670 & & & & 1,850 & & 14,657 \\
\hline L. America & 293 & & 1,415 & & & & & 291 & & 2,000 \\
\hline Europe & & & & 367 & & & & & & 367 \\
\hline FSU & 3,769 & & & 7,886 & 9,021 & 0 & 294 & 11,017 & & 31,988 \\
\hline Middle East & & & & 667 & & 1,007 & & 6 & & 1,680 \\
\hline Africa & 4,984 & & & 6,480 & & 0 & & 12,454 & & 23,918 \\
\hline Asia & & & & & & & & 2,380 & & 2,380 \\
\hline Oceania & 1,362 & & & 3,755 & & 0 & & 8,212 & & 13,329 \\
\hline World & 20,941 & 1,687 & 1,415 & 23,824 & 9,021 & 1,007 & 294 & 36,210 & 0 & 94,400 \\
\hline
\end{tabular}


Table 15 Enrichment trade (High demand scenario: 2020)

\begin{tabular}{|c|c|c|c|c|c|c|c|c|c|c|}
\hline & & & & & & & & & \multicolumn{2}{|c|}{ Unit: tSWL } \\
\hline From: $\quad$ To: & USA & Canada & L. America & Europe & FSU & Middle East & Africa & Asia & Oceania & World \\
\hline USA & 8,276 & & & 468 & & & & 8,205 & & 16,948 \\
\hline Canada & & & & & & & & & & c \\
\hline L. America & & & 168 & & & & & & & 168 \\
\hline Europe & & & 629 & 10,818 & & 327 & & 6,433 & & 18,207 \\
\hline FSU & 5,426 & & 129 & 4,302 & 5,902 & 332 & 192 & 6,537 & & 22,821 \\
\hline Middle East & & & & & & & & & & c \\
\hline Africa & & & & & & & & & & c \\
\hline Asia & & & & & & & & 2,517 & & 2,517 \\
\hline Oceania & & & & & & & & & & c \\
\hline World & 13,701 & 0 & 926 & 15,588 & 5,902 & 659 & 192 & 23,692 & 0 & 60,662 \\
\hline
\end{tabular}

than those that are currently in the planning stages, and it is more likely that the expansion plans of enrichment plants will be delayed.

\section{(2) Year 2035}

The demands for NU in 2035 in the high demand scenario will be 106,525 tU and 138,710 $\mathrm{tU}$, and those for UE services will be 138,521 tSWU and 90,117 tSWU in Price Cases I and II, respectively (with tails assays of $0.11 \%$ and $0.27 \%$ ).

In such a case, the demand for NU in Price Case II will exceed 112,512 tU in Production Case B, and even in Price Case I, the demand will be close to the level in Production Case B. The demand for UE services will significantly exceed the supply capacity in Enrichment Case $\mathrm{B}$, even in the Price Case II. This means it is highly likely that the supply-demand balance of NU will become tight in the high demand scenario, unless the NU production capacity and EU facilities steadily expand.

However, as in this case, if a steady growth in uranium production is expected, even after 2020 , it would be natural to assume that greater resources development investment will occur accordingly, and uranium production will further increase. Assuming Production Case C, where uranium production will grow at a rate that is half of that occurring between 2010 and 2020, production in 2035 will be 154,788 $\mathrm{tU}$ and will exceed demand with the tails assay of $0.27 \%$. Therefore, as long as steady development investment in uranium resources continue, a sufficient supply is expected, even if demand rises and the tails assay is high.

With respect to UE facilities, the required facility growth between 2020 and 2035 in Price Cases II and I is 17,817 tSWU and 66,221 tSWU, respectively. In particular, growth in Price Case $I$ is at a level that exceeds the current total capacity of global enrichment facilities, and to construct new facilities to cover the level, a significantly tight balance of supply and demand and a price rise in UE service costs would be required. However, as mentioned above, the supply and demand of NU itself would be satisfied, even if such rapid resource development was not be made. Therefore, in this case, it is also expected that tails assays will remain high and that construction of UE facilities will be minimal. The facility growth in Price Case II is $17,817 \mathrm{tSWU}$, which is equivalent to the capacity of three to four large-scale enrichment plants. It is not unrealistic to expect this level of facility construction between 2020 and 2035 . In this study, we established Case $\mathrm{C}$ which assumes that an enrichment plant with a capacity of $6,000 \mathrm{tSWU} / \mathrm{yr}$ would be constructed in the US, and that the remaining required facility growth would be covered by new construction in the former Soviet Union and China. The estimated results are presented in Tables 16 and 17 and Figures 8 and 9.

With respect to the supply and demand of NU, the demand in Asia will be significant, and 
INSIGHTS CONCERNING THE FUKUSHIMA DAIICHI NUCLEAR ACCIDENT Vol. 4

Table 16 Uranium trade (High demand scenario: 2035)

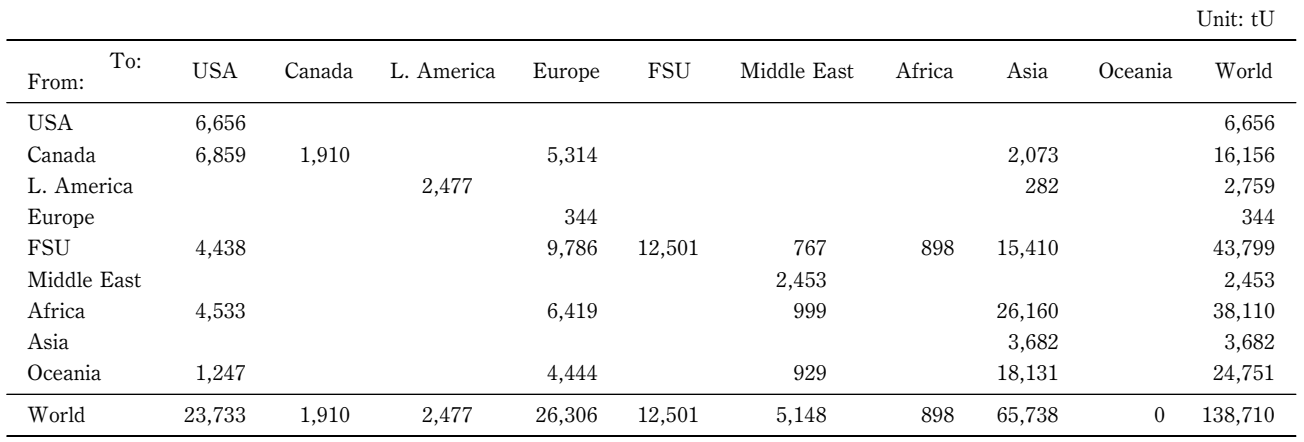

Table 17 Enrichment trade (High demand scenario: 2035)

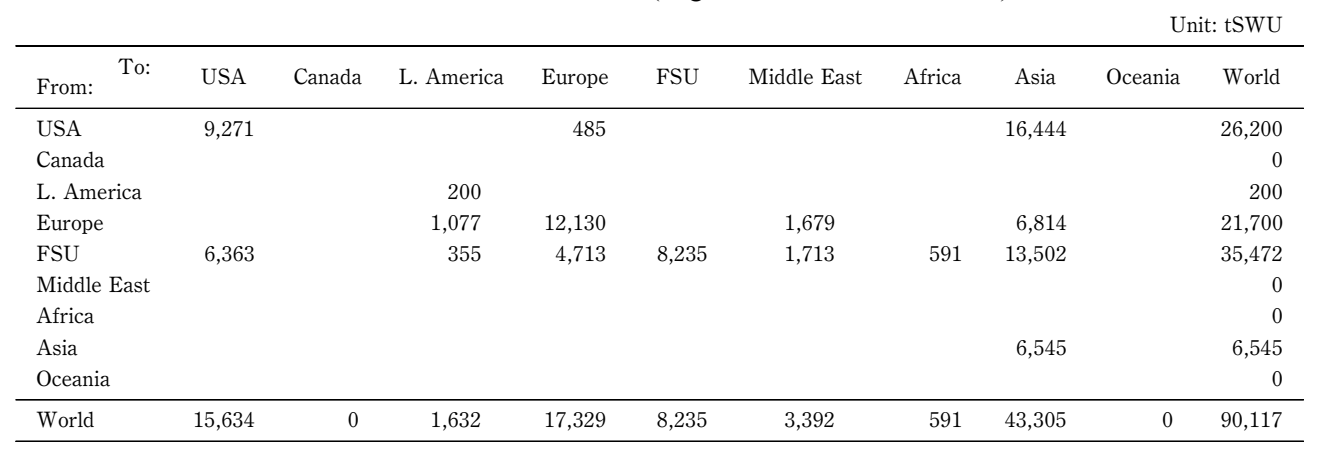

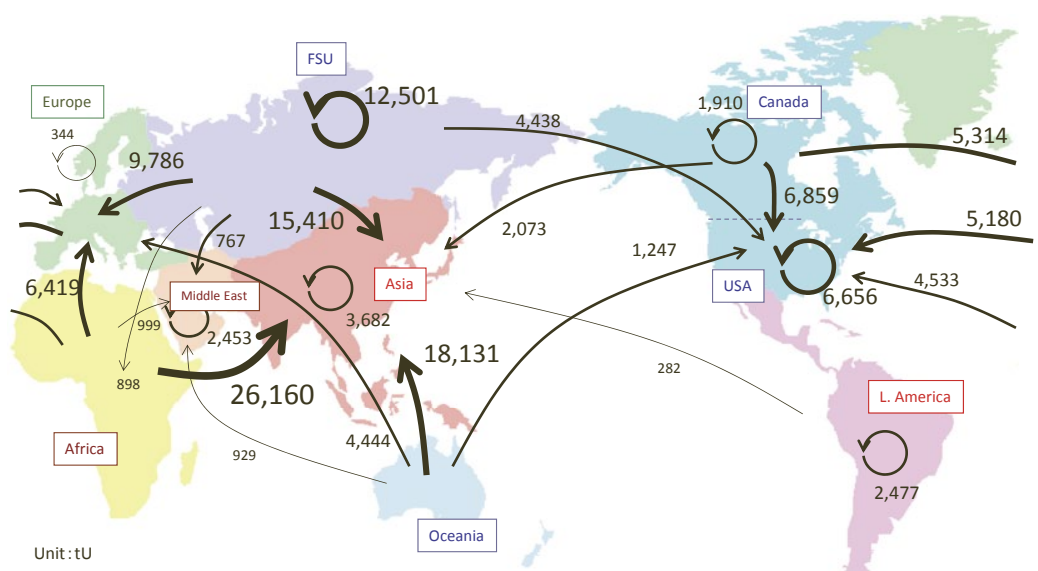

Figure 8 Uranium trade (High demand scenario: 2035)

$67 \%$ of global growth after 2020 will occur in this area. The demand for this growth will be covered by imports from the former Soviet Union, Africa, and Australia. However, as the demand for uranium will also increase in the former Soviet Union, the amount exported will be limited. In contrast, imports from Africa and Australia will largely expand.

Despite the new large-scale enrichment facilities assumed in China, the supply for UE 


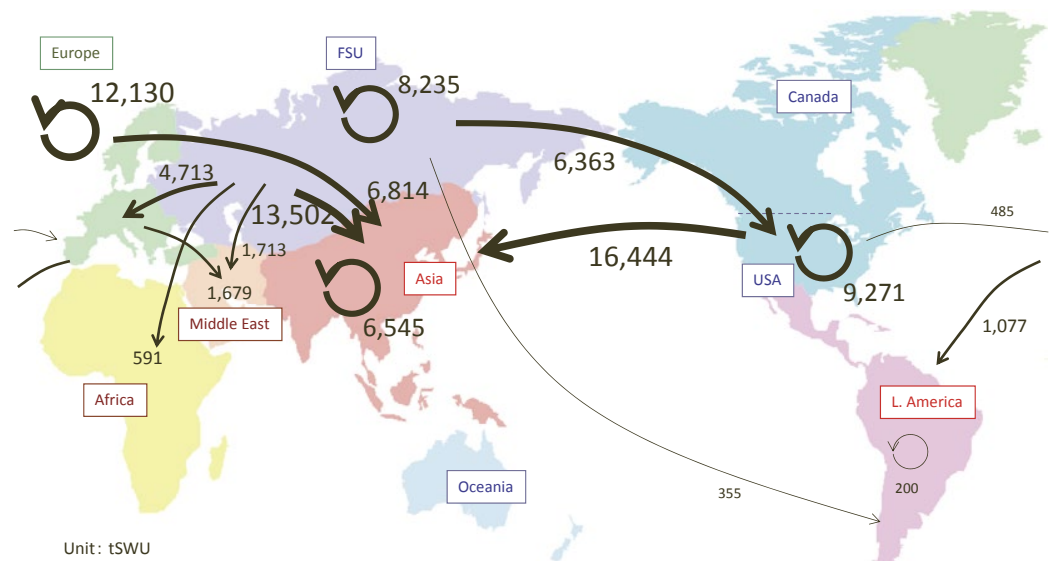

Figure 9Enrichment trade (High demand scenario: 2035)

Table 18 Uranium transport to enrichment facilities (High demand scenario: 2035, optimized with freight)

\begin{tabular}{|c|c|c|c|c|c|c|c|c|c|c|}
\hline & & & & & & & & & & Unit: $\mathrm{tU}$ \\
\hline From: $\quad$ To: & USA & Canada & L. America & Europe & FSU & Middle East & Africa & Asia & Oceania & World \\
\hline USA & 6,656 & & & & & & & & & 6,656 \\
\hline Canada & 11,655 & & & 4,501 & & & & & & 16,156 \\
\hline L. America & 2,450 & & 308 & & & & & & & 2,759 \\
\hline Europe & & & & 344 & & & & & & 344 \\
\hline FSU & 4,043 & & & 1,536 & 38,220 & & & & & 43,799 \\
\hline Middle East & & & & 2,453 & & & & & & 2,453 \\
\hline Africa & 13,914 & & & 7,816 & 16,380 & & & & & 38,110 \\
\hline Asia & & & & & & & & 3,682 & & 3,682 \\
\hline Oceania & 1,609 & & & 16,751 & & & & 6,391 & & 24,751 \\
\hline World & 40,328 & 0 & 308 & 33,401 & 54,599 & 0 & 0 & 10,074 & 0 & 138,710 \\
\hline
\end{tabular}

Table 19 Enrichment trade (High demand scenario: 2035, optimized with freight)

\begin{tabular}{|c|c|c|c|c|c|c|c|c|c|c|}
\hline \multicolumn{11}{|c|}{ Unit: tSWU } \\
\hline From: $\quad$ To: & USA & Canada & L. America & Europe & FSU & Middle East & Africa & Asia & Oceania & World \\
\hline USA & 13,100 & & & 17 & & & & 13,083 & & 26,200 \\
\hline Canada & & & & & & & & & & 0 \\
\hline L. America & & & 200 & & & & & & & 200 \\
\hline Europe & & & 0 & 12,927 & & 0 & & 8,773 & & 21,700 \\
\hline FSU & 2,534 & & 1,432 & 4,384 & 8,235 & 3,392 & 591 & 14,904 & & 35,472 \\
\hline Middle East & & & & & & & & & & 0 \\
\hline Africa & & & & & & & & & & 0 \\
\hline Asia & & & & & & & & 6,545 & & 6,545 \\
\hline Oceania & & & & & & & & & & 0 \\
\hline World & 15,634 & 0 & 1,632 & 17,329 & 8,235 & 3,392 & 591 & 43,305 & 0 & 90,117 \\
\hline
\end{tabular}

services in Asia will not be satisfied and will be supplied from Russia and the US.

In the high demand scenario for 2035, estimated results for the reference case where trade flows are optimized depending on the cost of transportation between regions is shown in Tables 18 and 19. Table 18 shows flows between NU production areas and UE facilities areas, unlike Table 16, which shows flows from uranium production to fuel demand areas. The values in 
Table 19 are largely similar to the estimated results shown in Table 17. In this case, as mentioned above, $50 \%$ of the amount provided by enrichment facilities in the US is assumed to be supplied for US demand. If estimations that eliminate this constraint are made, all enriched uranium in the US would be exported to Asia, and the supply from Russia would be sent to the US (because the total distance from Russia to the US and then the US to Asia is shorter than that from Russia to Asia via the Cape of Good Hope).

However, the supply of fuel between the US and Russia is determined based on sensitive political conditions and these have a large impact on the global supply and demand of fuel.

\section{Supply of NU and UE Services to Asia}

As mentioned above, Asia will be the center of nuclear power plants expansion. The demand share of NU and UE services in the region is assumed to increase from the current level of around $30 \%$ to around $40-50 \%$ in 2035 , depending on the case. It is thus crucial to determine how the demand growth in Asia can be met with regard to the future issue of uranium supply and demand.

Figures 10 and 11 show the supply of NU and UE services from other regions to Asia in the above cases. It is currently estimated that a considerable amount of NU will be supplied to Asia from the former Soviet Union (Russia, Kazakhstan, and other countries). However, in future, as seen from the estimated growth of nuclear power plants in this region, the former Soviet Union

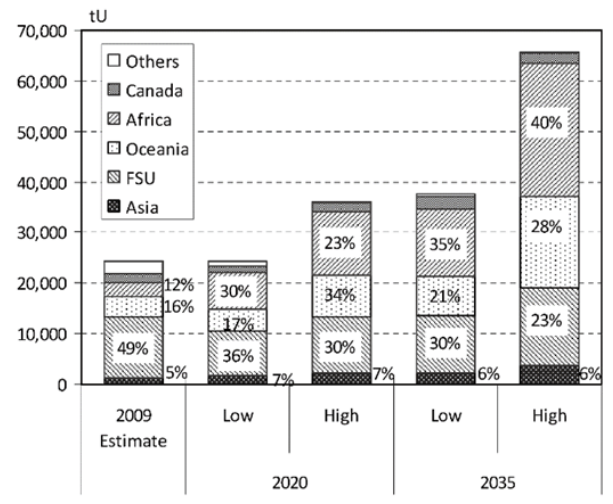

Figure 10 Uranium supply to Asia

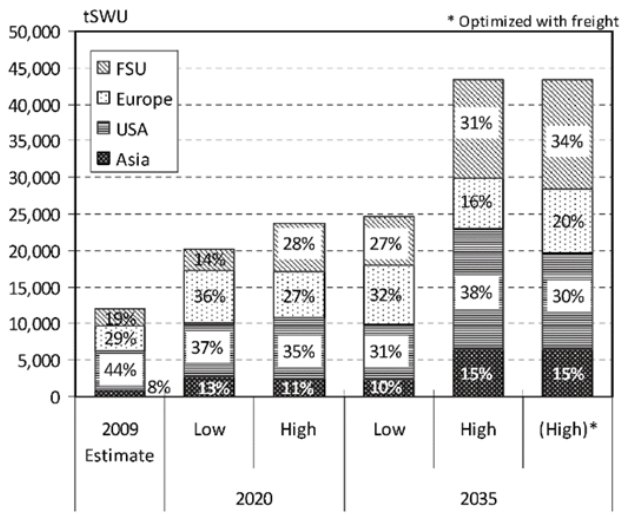

Figure 11 Enrichment supply to Asia 
(FSU) is not the region that will cover the growth demand. Instead, Africa will increase their supply in the medium and short term. As mentioned above, in the low demand scenario, where the growth of the global nuclear capacity is slower, it is supposed that the supply and demand balance of NU will be largely eased and that resource development will stagnate. In this case, there will be no significant increase in imports from any region other than Africa.

In the high demand scenario, where there is a maximum expansion of nuclear power capacities, imports from Australia and Africa will cover the rapid growth in demand, and imports from these two areas will cover $70 \%$ of the Asian demand in 2035 . However, production within Asia will only cover about $6 \%$ of the demand, and it is supposed their resource dependency on foreign countries will continue in the long run.

With respect to UE services, imports from the US, where the large-scale construction of new enrichment plants is planned, will increase in the medium term. However, the former Soviet Union is the area where exports will grow in accordance with long-term demand increases, and their importance will increase. In contrast, the supply share from Europe to Asia will decline, and there will be no significant increase in the supply share from Asia. As with the case of NU, it is supposed that Asia will depend on imports from other regions for long-term UE services. Figure 11 also shows results of the reference case, where the trade flow is optimized based on the cost of transportation between regions; results are largely similar to those for the high demand scenario in 2035 .

Figures 12 and 13 show changes in the self-sufficiency rate and the Herfindahl-Hirshman

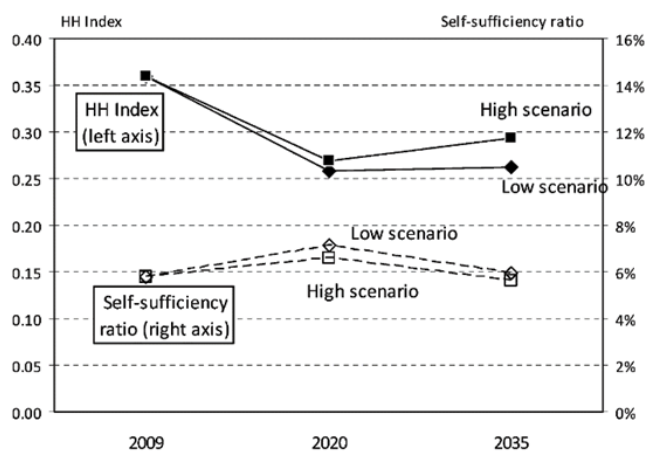

Figure $12 \mathrm{HH}$ index and self-sufficiency ratio (Uranium)

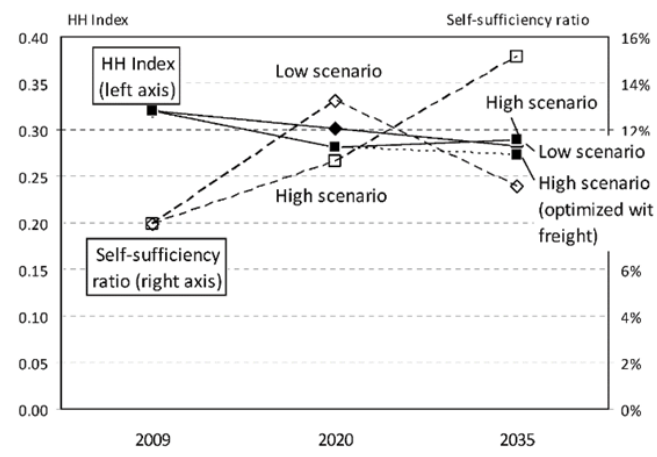

Figure $13 \mathrm{HH}$ index and self-sufficiency ratio (Enrichment) 
(HH) index of NU and UE services in Asia. As mentioned above, it is expected that NU self-sufficiency will remain at a very low level of about $6 \%$ until 2035, and UE services will increase up to about $15 \%$ in the high demand scenario in 2035 , due to the operation and launch of new enrichment facilitates. However, as also mentioned above, it is supposed that improving the self-sufficiency rate will be more difficult than this level from the view points of price and supply-demand balance.

The HH index indicates the diversity of NU and UE service suppliers to Asia, which can be expressed by Eq. (2). A lower value shows that the suppliers are more diverse, which is desirable for an importer from the perspectives of energy security,

$$
H H=\sum_{i}\left(\frac{a_{i}}{X}\right)^{2}
$$

where, $a_{i}$ indicates the supply amount from region i to Asia, and $\mathrm{X}$ indicates the total supply to Asia. As of 2009, the estimated HH index for NU is 0.36 and that of UE services is 0.32 . This index for NU is a little lower than the oil supply value (0.37) in Asia estimated based on the BP statistics ${ }^{31)}$. This is because, according to the actual record in 2009 , the supply ratio from the former Soviet Union is high. However, as seen in Figures 12 and 13, both indexes for NU and UE services will fall below 0.3, due to the increased supplies from Africa, Australia, and other regions for NU, and the well-balanced supply from three main regions (including Russia, the US, and Europe) for UE services. With respect to the reference case, the self-sufficiency rate in Figure 13 is the same value in the high demand scenario, and the HH index in Figure 13 is also nearly the same as the value in the high demand scenario.

\section{Conclusions}

This study estimates the trade flows of NU and UE services in the long term by considering nuclear power generation growth and increases in the NU production and UE capacities. It is expected that although nuclear capacity will continue to expand mainly in Asia in the future, the balance between the supply and demand of NU and UE services will be eased until 2020, due to NU resource development and the enhancement of UE facilities that are currently in the planning stage.

As a result, resource development and enrichment facility enhancement projects are likely to be significantly delayed in the mid-term. In the case where the growth of nuclear power generating capacities is slow, this trend will probably continue until 2035, and uranium production might decline from 2020. However, in the case where countries throughout the world promote nuclear power generation at a maximum level to maintain a stable supply of energy, and to provide measures to prevent global warming, more projects plans will need to be implemented (other than those that currently exist). Even if the implementation speed is relatively slow compared to those currently in the planning stage, it is projected that this will be sufficient to satisfy demand. These projections suggest that it is unlikely that the supply and demand balance will be tight for the next 20 to 30 years, as long as the development plans currently underway are implemented by around 2020 and new projects are launched in an appropriate manner that considers the future growth demand. From the relation between supply and demand of NU and UE services, it is projected that the tails assay will remain at a high level in the long term, which means that UE service prices will remain at a relatively high level compared to the price of NU.

Asia will be at the center of future demand growth, and its dependence on foreign resources 
for both NU and UE services will stay at a high level in the long term. With respect to NU, the demand will be covered by imports from Africa and Australia; and for UE services, it is estimated that Asia will rely on imports to a greater degree from the US and then from Russia. Nuclear energy is often considered a quasi-domestic energy from the perspective of its long fuel storage capability, in addition to domestic implementation of the nuclear fuel cycle and the reusability of spent fuel. As suggested by this study, it is supposed that a rise in the self-sufficiency rate of the production of NU and UE services will be difficult in Asia in the medium-term. However, the diversification of supply regions ( $\mathrm{HH}$ index) is projected to drastically improve compared to that of the oil supply, owing to progress made in global development plans. We can thus estimate that progress made in providing nuclear energy would contribute to energy security in Asia at a certain level.

If nuclear power plants expand even after 2035, which is the period studied in this paper, the supply and demand balance of NU resources and UE will become gradually tighter, depending on development trends in new uranium resources and UE facilities. However, with respect to the time span, it will be necessary to consider introducing various technologies that help mitigate the growth in demand for NU, including those relating to the use of FBRs and thorium resources, uranium extraction from seawater, and nuclear fusion. This also means that, as this estimation suggests, as long as the supply and demand for uranium is considered only until 2035, such innovative new technologies are not necessarily indispensable. Future studies will need to be conducted to determine in the longer term how we regard the use of such technologies.

Part of this research was conducted with the support of the Environment Research and Technology Development Fund of the Ministry of the Environment (S-6-1:General Research for Development, Estimation and Evaluation Methods for Meddle to Long Term Political Options and their Promotion for Low Carbon Society in Asia; Scenario Development for Establishment of Low Carbon Society for Asian Countries). We would like to express our deepest gratitude to the Ministry.

\section{References}

1) Ministry of Economy, Trade and Industry, The Strategic Energy Plan of Japan (2010).

2) International Energy Agency, World Energy Outlook 2011, IEA Publications, ISBN 9789264124134 (2011).

3) International Energy Agency, Energy Technology Perspectives 2010, IEA Publications, ISBN 9789264085978 (2011).

4) International Atomic Energy Agency, Energy, Electricity and Nuclear Power Estimates for the Period up to 2050, IAEA Vienna, ISBN 9789201194107 (2011).

5) OECD, Nuclear Energy Agency, Nuclear Energy Outlook 2008, OECD Publishing, ISBN 9789264054103 (2008).

6) U.S. Energy Information Administration, International Energy Outlook 2011, DOE/EIA-0484 (2011).

7) World Nuclear Association, The WNA Nuclear Century Outlook: Averting the Danger of Catastrophic Climate Change: Is the Nuclear Renaissance Essential?, WNA (2011).

8) OECD, International Energy Agency, Uranium 2009 Resources, Production and Demand, OECD Publishing, ISBN 9789264047907 (2009).

9) World Nuclear Association, The Global Nuclear Fuel Market: Supply and Demand 2011-2030, WNA (2011).

10) R. Komiyama, T. Kakinoki, "Long-term outlook for nuclear power generation and uranium demand and supply situations up to 2030 and 2100," Energy Keizai, 33[3], 1-24 (2007). [in Japanese]

11) T. Murakami, "Nuclear fuel demand and supply outlook up to 2030," Energy Keizai, 33[5], 22-34 (2007). [in Japanese]

12) Y. Matsuo, M. Aoshima, M. Kako et al., "Asia/world energy outlook 2011 - Growing uncertainty over international energy trends and the future of Asia-," IEEJ Energy J., 7[1], 17-55 (2012). 
13) Y. Matsuo, “U. S. nuclear energy policy and Japan's nuclear industry expansion trends," IEEJ Energy J., 6[2], 27-42 (2011).

14) U. S. Energy Information Administration, Annu. Energy Outlook 2011, DOE/EIA-0383 (2011).

15) National Energy Board, Canada's Energy Future: Energy Supply and Demand Projections to 2035, ISBN 9781100194646 (2011).

16) Japan Atomic Industrial Forum, World Nuclear Power Plants 2011, JAIF (2011).

17) Denki Shimbun, Nuclear Pocket Book, The Japan Electric Association, ISBN 9784905217053 C0550 (2011). [in Japanese]

18) World Nuclear Association Website, http://www.worldnuclear.org/

19) Japan Atomic Energy Agency, Oubei ni Okeru Kakunenryou Saikuru ni Kansuru Chousa (A Report on Nuclear Fuel Cycle in Europe and North America FY 2007), (2008). [in Japanese]

20) Areva, 2011 Reference Document (2011).

21) URENCO, Annual Report and Accounts 2011 (2011).

22) Ux Consulting Website, http://www.uxc.com/

23) H. Hirai, Y. Matsuo, Y. Nagatomi, "Supply and demand analysis on petroleum products and crude oil for Asia and the world," IEEJ Energy J., 3[3], 29-60 (2008).

24) Y. Kobayashi, "Natural gas situation and LNG supply/ demand trends in Asia-Pacific and Atlantic markets," IEEJ Energy J., 5[1], 65-96 (2010).

25) P. Diehl, Re-enrichment of West European Depleted Uranium Tails in Russia, WISE Uranium Project, http://www.wiseuranium.org, (2004).

26) Poten and Partners, Estimated Voyage Costs — Round Trip Economics (2011).

27) U. S. Committee on the Internationalization of the Civilian Nuclear Fuel Cycle, Committee on International Security and Arms Control, National Academy of Sciences and National Research Council, Internationalization of the Nuclear Fuel Cycle: Goals, Strategiesand Challenges, The National Academies Press, ISBN 9780309126601 (2009).

28) NAC International, Selected Aspects of the Fuel Cycle Front End (2011).

29) World Scale Association, New Worldwide Tanker Nominal Freight Scale (2010).

30) PESCO Co., Ltd, Kakunenryou Saikuru Shisetsu, Gijutsu tou ni Kakaru Doukou Chousa (A Report on Nuclear Fuel Cycle Facilities and Technologies) (2009). [in Japanese]

31) BP, Statistical Review of World Energy June 2012 (2012). 